UNITED STATES

DEPARTMENT OF THE INTERIOR

GEOLOGICAL SURVEY

\title{
PHOTOGEOLOGIC AND KINEMATIC ANALYSIS OF LINEAMENTS AT YUCCA \\ MOUNTAIN, NEVADA; IMPLICATIONS FOR STRIKE-SLIP \\ FAULTING AND OROCLINAL BENDING
}

by

\author{
J. Michael O'Neill', John W. Whitney', \\ and Mark R. Hudson 1
}

\section{DISCLAIMER}

${ }^{1}$ Denver, Colorado

This report was prepared as an account of work sponsored by an agency of the United States This report was prepared as an account Government nor any agency thereof, nor any of their employees, makes any warranty, express or implied, or assumes any legal liability or responsibility for the accuracy, completeness, or usefulness of any information, apparatus, product, or process disclosed, or represents that its use would not infringe privately owned rights. Reference herein to any specific commercial product, process, or service by trade name, trademark, manufacturer, or otherwise does not necessarily constitute or imply its endorsement, recommendation, or favoring by the United States Government or any agency thereof. The views and opinions of authors expressed herein do not necessarily state or reflect those of the United States Government or any agency thereof. 


\section{CONTENTS}

Page

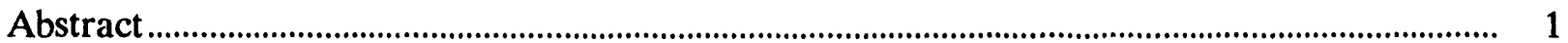

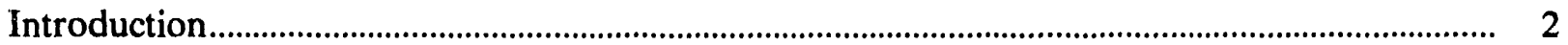

General physiographic character of Yucca Mountain area .................................................................... 2

Description of major photogeologic lineaments.................................................................................. 2

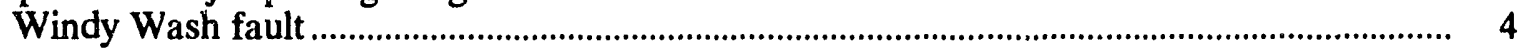

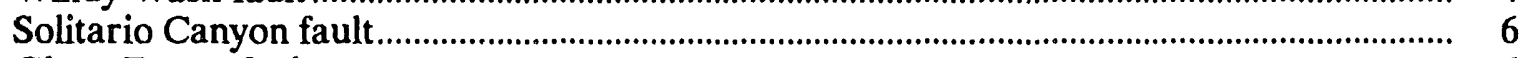

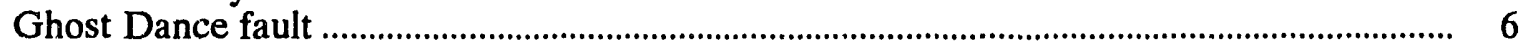

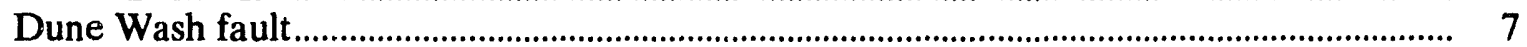

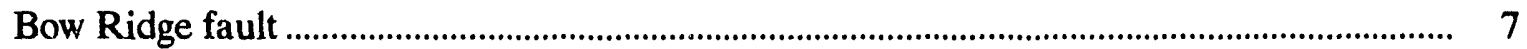

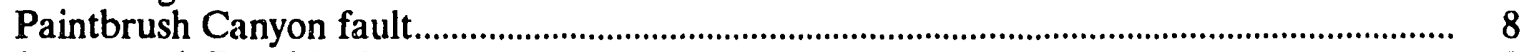

Stagecoach Road fault ........................................................................................................... 8

Northwest-trending topographic features ................................................................................ 8

Miscellaneous photogeologic features................................................................................... 9

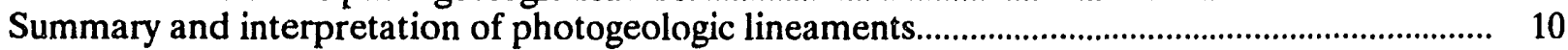

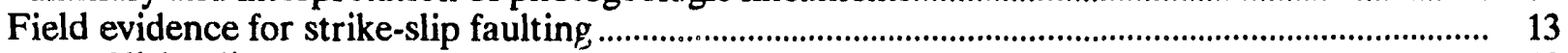

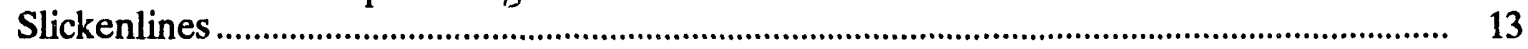

Paintbrush Canyon fault.................................................................................. 13

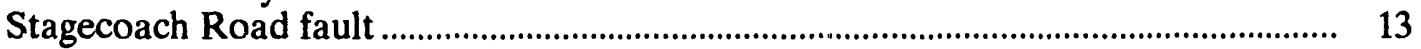

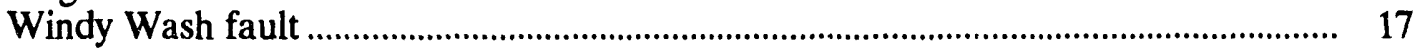

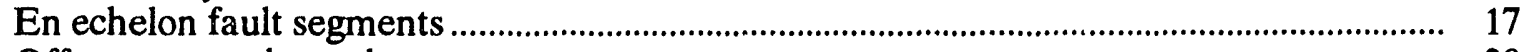

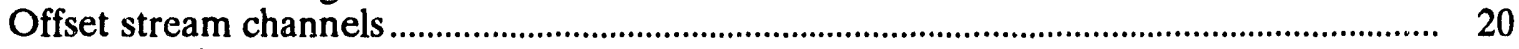

Paleomagnetic evidence for oroclinal bending at Yucca Mountain

and implications for left-lateral strike-slip faulting ......................................................... 20

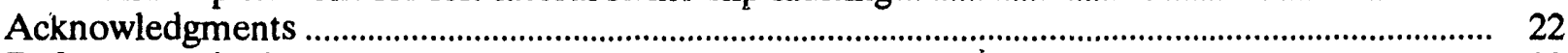

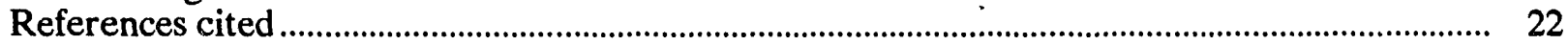

\section{ILLUSTRATIONS}

Plate 1.--Photogeologic lineament map of Yucca Mountain, Nye County, Nevada ......... In pocket

Figure 1.--Index map of the Yucca Mountain area showing outline of map area and location and names of previously mapped faults.

Figure 2.--(a) Enlargement of low-sun angle aerial photograph of a segment of Windy

Wash fault showing en echelon, left-stepping fault segments;

(b) tracing of figure 2a showing location of Windy Wash fault and short, northwest-trending fault segments that connect the main fault.

Figure 3.--The orientation of folds and faults expected in an area that has undergone left-lateral strike-slip faulting. 


\section{ILLUSTRATIONS--Continued}

Page

Figure 4.--(a) Photograph of Paintbrush Canyon fault along west side of Fran Ridge showing southwesterly inclined slickenlines preserved on fault plane;

(b) lower hemisphere equal-area projection showing a bipolar density of poles to fault plane segments along the Paintbrush Canyon fault in area of figure 4a and the density of azimuth and plunge of slickenlines preserved on these fault planes; (c) lower hemisphere, equal area projection showing the two preferred orientations of fault planes determined from figure $4 \mathrm{~b}$ and the preferred orientation of slickenlines

Figure 5.--(a) Lower hemisphere stereographic projection showing orientation of three segments of the Stagecoach Road fault and the azimuth and plunge of slickenlines on each surface; (b) lower hemisphere stereographic projection showing orientation of a probable splay of the Stagecoach Road fault exposed north of the old stagecoach road and azimuth and plunge of slickenlines preserved on fault plane

Figure 6.--Photograph of probable splay of Stagecoach Road fault

Figure 7.--Photograph of smooth colluvial slope disrupted by the larger pull-apart graben shown on figure 2 along the Windy Wash fault....

Figure 8.--(a) Photographs of Paintbrush Canyon fault along the west side of Fran Ridge showing the left-stepping, en echelon outcrop pattern of fault segments; (b) apparent fold in Quaternary-Tertiary alluvium in wedge-shaped area along the Windy Wash fault.

Figure 9.--Schematic diagram showing idealized morphology of stream channels offset in a left-lateral sense across fault scarps

Figure 10.--Block model showing clockwise block rotation and left-lateral strike-slip faulting during rigid body deformation. 


\title{
UNITED STATES \\ DEPARTMENT OF THE INTERIOR \\ GEOLOGICAL SURVEY
}

\section{PHOTOGEOLOGIC AND KINEMATIC ANALYSIS OF LINEAMENTS AT YUCCA MOUNTAIN, NEVADA: IMPLICATIONS FOR STRIKE-SLIP FAULTING AND OROCLINAL BENDING}

by

\author{
J. Michael O'Neill, John W. Whitney, \\ and Mark R. Hudson
}

\begin{abstract}
The main structural grain at Yucca Mountain, as seen from aerial photographs, is a pronounced north-trending linear fabric defined by parallel, east-tilted fault-block ridges. The ridges are bounded on the west by normal faults that are easily recognizable on aerial photographs, mainly as isolated, colinear scarps in alluvium and as offset bedrock units. All ridge-bounding faults in this area are structurally connected to adjacent faults, most commonly by short northwesttrending fault splays. The generally north-trending high-angle faults primarily display down-to-thewest normal offset, but also have an auxiliary component of left-lateral slip. Left-lateral slip is indicated by offset stream channels, slickenlines, and en echelon fault splays that are structurally linked, commonly by pull-apart grabens. These grabens, best seen on low-sun angle aerial photographs, range from tens of meters to more than 3 kilometers wide. The smallest pull-apart zones are well developed along the Windy Wash and Solitario Canyon faults on the west side of Yucca Mountain; the largest of these features is interpreted to structurally link the Bow Ridge and Solitario Canyon faults in the north-central part of Yucca Mountain; the pronounced northwesttrending drainage system in this part of Yucca Mountain appears to be controlled by tension fractures related to left-lateral strike-slip movement on these north-trending faults. Midway Valley, directly east of this pull-apart graben, may also owe its origin, in part, to a pull-apart mechanism.
\end{abstract}

Paleomagnetic data from Miocene ash-flow sheets indicate that Yucca Mountain has undergone a southward-increasing clockwise vertical-axis rotation as large as $30^{\circ}$ since about 13 Ma. Left-lateral offset along Yucca Mountain faults is interpreted to reflect displacements between rigid fault blocks within a structural domain undergoing clockwise, "domino style" rotation. 


\section{INTRODUCTION}

The Yucca Mountain area in southern Nevada is physiographically dominated by northtrending ridges that are underlain by thick accumulations of Miocene ash-flow tuffs. Normal faulting in this area (fig. 1) is a reflection of regional scale crustal extension of the southern Great Basin that began as early as middle Cenozoic time (Hamilton, 1988; Fox and Carr, 1989). Extension that produced the present-day topography at Yucca Mountain began after the eruption of the Miocene ash-flow sheets and has been recurrently active into the Holocene (Fox and others, 1990). Although the dominant movement along the faults at Yucca Mountain is normal, a component of strike-slip displacement is present (Scott and Bonk, 1984; Scott, 1990). Evidence suggesting right-lateral strike-slip was based mainly on the presence of nearly horizontal slickenlines in northwest-trending faults that parallel the right-lateral Las Vegas shear zone exposed southeast of Yucca Mountain. Evidence suggesting sinistral slip on northeast-trending faults included left offset of vertical veins in bedrock and surface stream channels. Lineament analyses of the region made during this study, using low-sun angle aerial photographs flown at a scale of 1:12,000, supplemented by later field investigations along selected faults, has revealed that strike-slip movement is more pronounced than previously recognized.

\section{GENERAL PHYSIOGRAPHIC CHARACTER OF YUCCA MOUNTAIN AREA}

The main structural grain of the Yucca Mountain area (fig. 1), well depicted on aerial photographs, is the pronounced north-trending, east-tilted fault blocks bounded on the west by normal faults (Fox and others, 1990). Each fault block is separated from the adjacent blocks by narrow, alluvial-filled valleys. The fault blocks terminate on the north against northwest-trending Yucca Wash that separates Yucca Mountain from the southern flank of the large Timber Mountain caldera complex, distinguished by its irregular topography and complex drainage systems (fig. 1; pl. 1). The northern part of Yucca Crest is characterized by a series of northwesttrending, narrow, linear ridges and valleys. On the south, narrow prongs of Yucca Crest and adjacent fault blocks plunge gently beneath the alluvium of the northeastern reaches of the Amargosa Desert (pl. 1).

\section{DESCRIPTION OF MAJOR PHOTOGEOLOGIC LINEAMENTS}

Major faults in the Yucca Mountain area have been recognized and mapped by numerous workers, including Scott and Bonk (1984), Swadley and others, (1984), and Fox and others (1990). These faults, as previously mapped, are shown on figure 1 and are named, from west to east: the north-trending Windy Wash, Solitario Canyon, Ghost Dance, Bow Ridge, and Paintbrush Canyon faults, and the northeast-trending Stagecoach Road fault. These faults are also recognizable on low-sun angle aerial photographs as poorly to well-defined lineaments that are defined mainly by scarps in alluvium, by offset of bedrock, and by linear, north-trending fault blocks. Plate 1 shows our compilation of lineaments detected on aerial photographs that define these major faults. A pronounced northwest-trending topographic fabric dominates the north-central part of the map area and is associated with small, similarly oriented faults and linear features (for example, vegetation and drainage alignments, and tonal contrasts on the photos) that are most abundant in the east. Descriptions of the following photogeologic features are based on map patterns shown on plate 1 . 


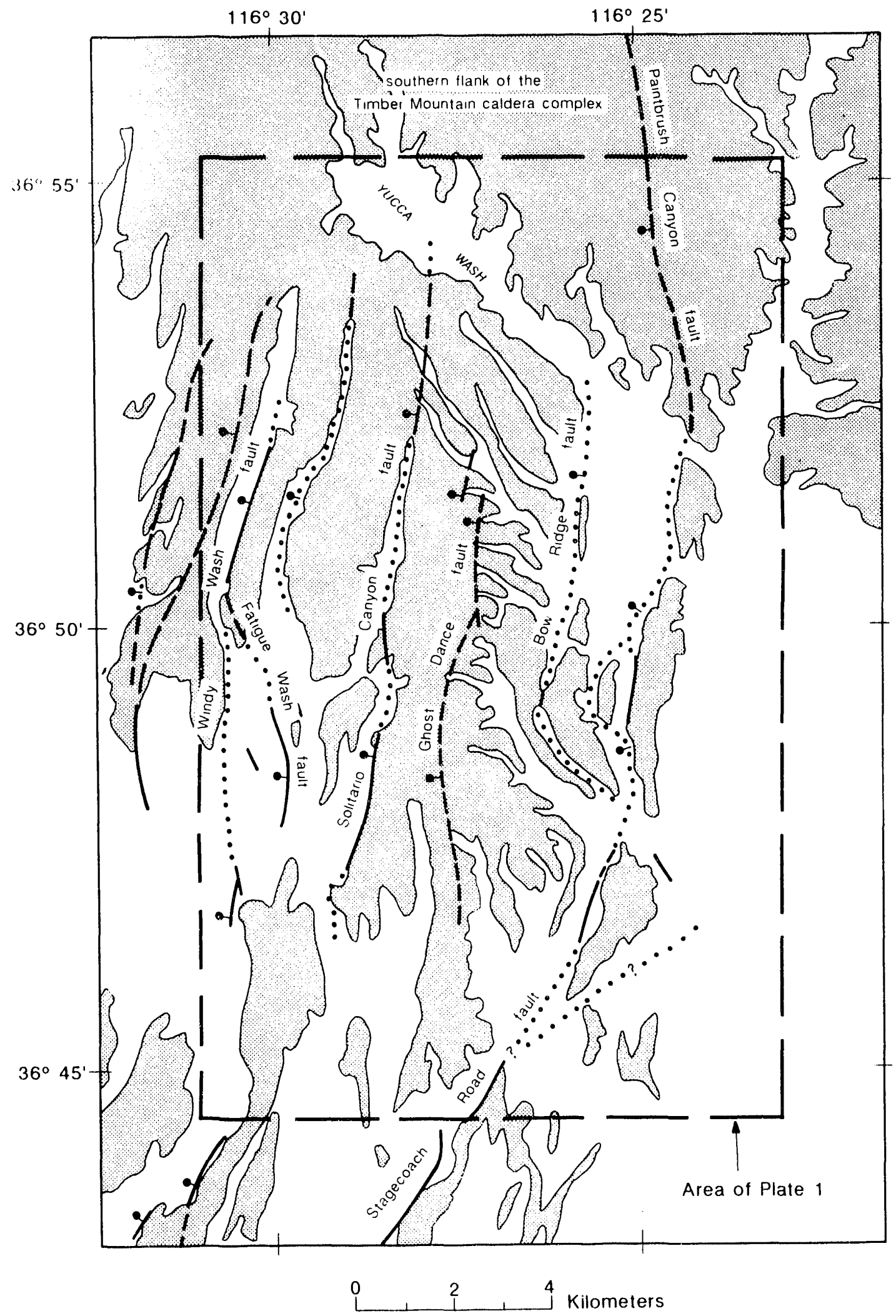

Figure 1.--Index map of the Yucca Mountain area showing outline of map area and location and names of previously mapped faults (after Fox and Carr, 1989). 


\section{Windy Wash Fault}

The Windy Wash fault, south of the map area, trends north as a single fault zone (Swadley and others, 1984; Scott, 1990; Fox and others, 1990, fig. 3) (plate 1), but in the southwestern corner of the map area it splits into three distinct splays. The westernmost splay (www, pl. 1) can be traced into Crater Flat as a series of aligned scarps, tonal contrasts, and linear-drainage segments; the fault appears to cross Crater Flat and die out in bedrock on the north. An unusual feature along this splay at the south is a wedge-shaped area (ww1) associated with linear fault scarps on the east and west. This wedge is elevated with respect to the adjacent area and bordered by a fault on the west side that is down-to-the-west and by a fault on the east side that is down-to-the-east.

The central splay of the Windy Wash fault (wwc) trends north toward the upper part of Windy Wash as a series of small right- and left-stepping en echelon scarps in alluvium. Most scarps of the central splay trend slightly west of north and probably represent fault segments that are continuous with the Windy Wash fault of Scott and Bonk (1984) along the west side of West Ridge in the valley drained by the upper reaches of Windy Wash (pl. 1). Well-developed fault scarps and a pull-apart graben (ww2) are present along the northern part of this fault in Windy Wash (pl. 1, fig. 2). The pull-apart graben occurs where the fault steps left in an en echelon fashion, disrupting smooth surfaces developed on colluvium and structurally linking the two fault segments. Farther north, in the vicinity of The Prow, the Windy Wash fault zone is marked by a series of subparallel fractures and topographic and tonal-contrast lineaments of probable tectonic origin.

A third major splay (wwe) of the Windy Wash fault in the southwesternmost part of the map area appears to structurally link this fault with the Solitario Canyon fault. This structural connection is suggested by small faults, lefi-stepping en echelon fault segments and associated rhomboid-shaped breccia zone (ww3), and colinear topographic features.

The Fatigue Wash fault, directly east of Windy Wash (pl. 1), appears to merge with the Windy Wash fault in the north; it crosses the crest of West Ridge and down-drops the southern part of the ridge to the southwest. The Fatigue Wash fault is the main fault bounding the west side of Jet Ridge and cannot be traced south of the ridge. The east side of Jet Ridge is also cut by a west-dipping normal fault that separates Boomerang Point from the main part of the ridge at the south (pl. 1). This fault and two shorter topographic lineaments along the east side of Boomerang Point appear to continue south of Solitario Canyon Wash as small faults that cut bedrock in the low-lying Plug Hill.

A series of generally north-trending small faults and topographic and drainage alignments are associated with minor northwest-trending dike-filled fractures in the extreme northwestern part of the map area. These features appear to define a diffuse zone of minor faulting that lies west of the main strand of the Windy Wash fault and that may merge with the latter fault in the west-central part of the map area. These features, if they are a reflection of normal faulting at Yucca Mountain, appear to be minor structures. 

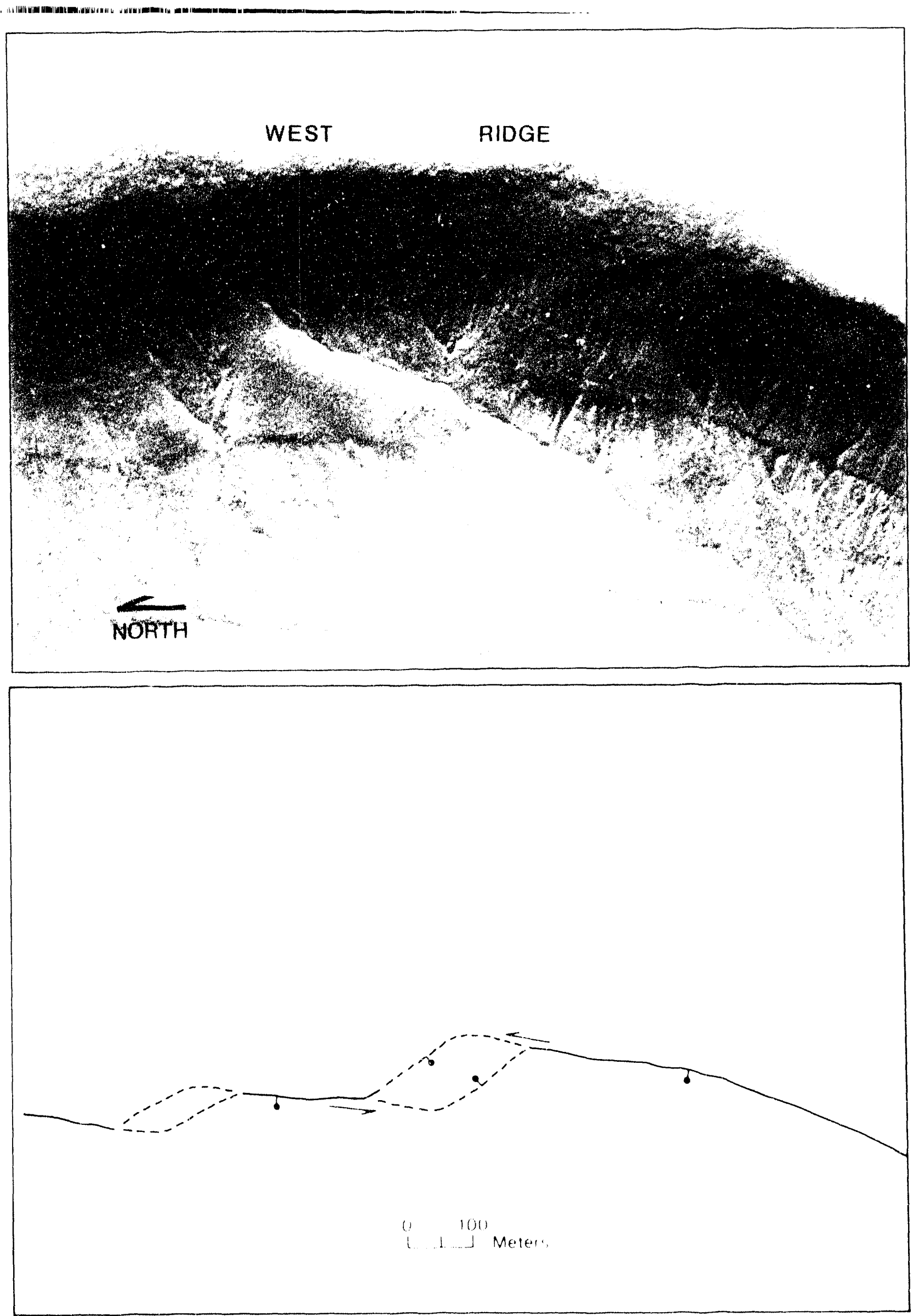

Figure 2.--(a) Fnlargement of low-sun angle aerial photograph of a segment of Windy Wash fault (ww2 on pl. 1) showing en echelon. left-stepping fault segments; (b) tracing of figure 2 at showing location of Windy Wash fault and short. northwest-trending fitult segments that connect the main fiult. 


\section{Solitario Canyon Fault}

The Solitario Canyon fault bounds the west side of Yucca Crest, the most pronounced north-trending ridge in the Yucca Mountain area. This ridge terminates on the north at Little Prow against Drill Hole Wash, the southernmost of several major northwest-trending valleys that dissect the northern part of Yucca Mountain. To the south, Yucca Crest splits into three lower, north-trending ridges herein informally called West Crest, Middle Crest, and East Crest (pl. 1). The Solitario Canyon fault bounds the west sides of West Crest and Yucca Crest. At the south end of West Crest the Solitario Canyon fault splits into three segments. The western splay (wwe), as discussed above, appears to tectonically link the Solitario Canyon fault with the Windy Wash fault. The central splay ( $\mathrm{scc}$ ) is marked by topographic and drainage lineaments and extends southward for only several hundred meters. This splay is approximately colinear with minor surface tonalcontrast and subtle topographic and drainage lineaments in alluvial material about $4 \mathrm{~km}$ further south. The east splay (sce) trends southeast across West Crest, dropping the south end of the crest down to the southwest.

The central and main parts of the Solitario Canyon fault are marked by two left-stepping fault segments linked by a crude, rhomboid-shaped disturbed zone (sc1) similar in shape to the pull-apart graben present along the northern part of the Windy Wash fault. Farther north, two northeast-trending splays of the fault cut Yucca Crest; the southernmost of these splays (sc2) is defined by a series of topographic lineaments that can be traced across Yucca Crest for nearly 3 $\mathrm{km}$. Directly west of Little Prow, at the head of Solitario Canyon, the displacement on the Solitario Canyon fault is minor.

The northern segment of the Solitario Canyon fault, north of Little Prow, dips east and displacement is down-to-the-east. This segment of the fault can be traced across all northwesttrending valleys and ridges in the northern part of Yucca Mountain and terminates south of Yucca Wash. Thus, the Solitario Canyon fault appears to show a complex scissors movement; on the south the hanging wall is on the west and on the north the hanging wall is on the east.

\section{Ghost Dance Fault}

Bedrock exposed in east-trending ridges along the east side of Yucca Crest is cut by several faults. The principal fault in this area is the Ghost Dance fault, which, although readily recognized and mapped on the ground (Scott and Bonk, 1984; Swadley and others, 1984), is less obvious on aerial photographs (pl. 1). The fault is marked by a series of colinear topographic features that cut across the east-trending ridges adjacent to Yucca Crest. The Ghost Dance fault appears to terminate on the north near Drill Hole Wash.

To the south, the Ghost Dance fault trends toward a complex zone of north- to northwesttrending faults and fault segments that converge northward. These segments, which were in part mapped and named by Scott and Bonk (1984), are from west to east.

1. An unnamed, previously mapped fault along the west side of Middle Crest (Carr, 1984;

Maldonado, 1985; Frizzell and Shulters, 1990; Reheis and Noller, 1990), marked in the south and central parts by small scarps and in the north by topographic and tonal-contrast lineaments.

2. The Abandoned Wash fault that down-drops Yucca Crest against Middle Crest and is marked by pronounced topographic lineaments. The extension of this fault to the south is tenuous; it appears to curve southwestward into a topographic gap in Middle Crest and may join the previously described fault that bounds the west side of Middle Crest.

3. An unnamed, previously mapped fault that bounds the west side of East Crest and separates 
Middle Crest from East Crest. The fault is marked by small west-facing scarps on the south and colinear fractures in bedrock on the north where it crosses East Crest.

4. Two parallel zones of unnamed, closely spaced north- to northwest-trending faults along the east flank of East Crest, marked by topographic and tonal-contrast lineaments, minor fractures, and offset of bedrock.

\section{Dune Wash Fault}

The Dune Wash fault, named and mapped by Scott and Bonk (1984) as a largely concealed structure beneath the central part of Dune Wash, is not obvious on aerial photographs; however, several topographic alignments along the west side of Dune Wash in the south, tonal contrasts at the head of the wash, and topographic lineaments along the west side of Boundary Ridge (pl. 1), may be photogeologic evidence for this structure. A series of north-trending, subtle topographic features cutting across the low mountain spurs directly north of Boundary Ridge may represent the northward continuation of the Dune Wash structure. These topographic features coincide with a series of small faults mapped by Scott and Bonk (1984). Two short southeast-trending linear features associated with the north-trending Dune Wash fault cut Boundary Ridge and were mapped previously as small faults by Scott and Bonk (1984).

\section{Bow Ridge Fault}

The Bow Ridge fault bounds the main part of Midway Valley on the west (east-central part of map area). The fault, on 1:12,000-scale aerial photographs, is perhaps the least obvious of the previously mapped faults in the Yucca Mountain area. The trace of the fault is marked by northtrending tonal contrasts and drainage alignments along the west side of Exile Hill and by segmented, left-stepping drainage alignments to the north (pl. 1). The southward extension of the fault, as mapped by previous workers (fig. 1), is not clear on aerial photographs; a small scarp is present in the low pass between Bow and Boundary Ridges where previous workers projected the trace of the fault. South of this pass the fault could not be recognized.

The Bow Ridge fault and the shorter, parallel, northward extension of the Dune Wash fault to the west appear to be structurally connected by short northwest-trending fault segments on Boundary Ridge. Similarly, a series of linear drainages, tonal contrasts, and linear vegetation alignments extend intermittently from the north end of Bow Ridge southeastward past the south end of Fran Ridge into alluvium on both sides of Fortymile Wash. At its northwesternmost position on Bow Ridge these linear features coincide with a small fault mapped by Scott and Bonk (1984). These features may represent a fault zone that connects the Bow Ridge fault with the Paintbrush Canyon fault that bounds Midway Valley on the east.

Numerous lineaments identified on aerial photographs are present in Midway Valley. These features, 200 to $500 \mathrm{~m}$ in length, trend north to northwest and are marked by tonal contrasts, drainage segments, vegetation alignments, and topographic scarps. A series of these colinear, northwest-trending features can be traced from the northern end of the Bow Ridge fault southeastward through the topographic gap between Alice Point and Fran Ridge into Fortymile Wash. Many of these lineaments in the Midway Valley alluvium are subparallel to the prominent northwest-trending drainages on the east side of Yucca Crest and to northwest-trending faults that cut Alice Point. The significance of these features is not clear, but speculations as to their origin are presented in the latter part of this report. 


\section{Paintbrush Canyon Fault}

The Paintbrush Canyon fault is one of the major faults of the Yucca Mountain region (fig. 1); it appears to merge with the Stagecoach Road fault on the south, and extends northward into the Paintbrush Canyon area along the southern flank of the Timber Mountain caldera complex (Swadley and others, 1984; Fox and others, 1990). Evidence for the extent of this fault, as determined from analyses of lineaments in this study, is not persuasive. A fault is present along the east side of Midway Valley and is marked by north-trending, segmented fault scarps along the west sides of Alice Point and Fran Ridge. But north of Yucca Wash, pre-Quaternary rocks of the Paintbrush Canyon area are characterized by numerous unconnected north-trending lineaments defined by small faults, tonal contrasts, drainage alignments, topographic features, fractures, and igneous dikes; a continuous, north-trending lineament indicating a northward extension of the Paintbrush Canyon fault is not evident. To the south, topographic scarps on the west side of Busted Butte may be evidence for the southward continuation of this fault, as shown by Fox and others (1990). Deep arroyos cut into sand ramps along the northwest side of Busted Butte expose faults (Whitney and others, 1986), not evident on aerial photographs, that have offset Quaternary soils as much as $4 \mathrm{~m}$. These faults are located in gullies directly north of the small fractures detected on aerial photographs on the west side of Busted Butte (pl. 1). Busted Butte itself is cut by a significant north-trending fault that is down-to-the-west; however, this fault is unique in that it appears to be a reverse fault on the north, becoming nearly vertical on the south. A second normal fault cuts the southwest-trending arm of the butte, but cannot be traced into the adjacent alluvium.

\section{Stagecoach Road Fault}

The Stagecoach Road fault, the only major northeast-trending structure in this area, is exposed only in the extreme south-central part of the map area (pl. 1). Color-contrast and topographic lineaments are present along the old stagecoach road and are continuous with welldeveloped scarps south of the map area. The main strand of the fault appears to trend eastnortheast toward a linear topographic break that is followed by the old stagecoach road directly south of Busted Butte. Tonal contrasts in alluvium directly north of the old stagecoach road in the extreme south-central part of the map area trend toward the west side of Busted Butte and may reflect buried structures that link this fault with the Paintbrush Canyon fault (for example, see Fox and Carr, 1989; Scott, 1990, p. 265).

\section{Northwest-Trending Topographic Features}

The pronounced northwest-trending ridges and associated canyons bounded by Yucca Wash on the north and Drill Hole Wash on the south dominate the topography in the north-central part of the map area. The Solitario Canyon fault cuts across all of these topographic features; however, in this area, the fault shows down-to-the-east normal displacement, opposite that of the main, longer strand of the fault to the south. 
Northwest-trending photogeologic lineaments suggestive of faults parallel to the northwesttrending ridges and valleys are not common. Yucca Wash contains a series of northwest-trending, colinear drainage segments where it enters Midway Valley. To the northwest, subparallel lineaments in the upper reaches of the wash are present only in bedrock along the south side of the wash, directly north of The Prow (pl. 1); these lineaments coincide only in a general way with faults mapped by Scott and Bonk (1984). The elongate saddle that separates Castle Point from Isolation Ridge to the southeast is cut by several faults and subparallel fractures that cannot be traced in alluvium in Yucca Wash. These features appear to continue southeast into Sever Wash where they are represented by short fracture segments in the valley bottom (pl. 1). A small fault, down-to-thesouthwest, terminates against the Solitario Canyon fault at the head of the northwest-trending Pagany Wash. The abrupt change in topographic grain from south to north across Drill Hole Wash suggests that a major northwest-trending fault may be buried beneath the alluvium of this valley. Faults have been observed in drill holes spudded in Drill Hole Wash (Spengler and Rosenbaum, 1980; Spengler and others, 1981) and several faults have been mapped in and adjacent to the wash by Scott and others (1984). Several northwest-trending fractures, topographic alignments, and tonal contrast lineaments are also present along the west side of the Solitario Canyon fault.

\section{Miscellaneous Photogeologic Features}

Several anomalous geologic features were observed on aerial photographs of the Yucca Mountain area. These include reverse faults, apparent synclinal folds adjacent to faults, and large landslide blocks.

The crest of Busted Butte appears to be cut by a north-trending reverse fault (pl. 1). The fault is down-to-the-west, as are most normal faults of the area, but clearly dips east on the north, becoming vertical at its south end. A second reverse fault appears to cut across East Crest, southeast of Yucca Crest. This fault dips northwest and is downthrown to the southeast.

Two synclinal folds appear to be present at Yucca Mountain--an area that is otherwise dominated by uniformly east-dipping strata. The largest fold, present on The Prow, trends northwest and is marked on aerial photos by a subtle, apparent reversal in dip of the volcanic rocks that underlie the ridge crest. A similar structure is present at the south end of West Crest; the apparent fold lies between fault splays scc and sce of the Solitario Canyon fault, and is also marked by a gentle reversal in dip of volcanic strata. The larger fold at The Prow was not mapped by Scott and Bonk (1984). Outcrop patterns, shown by these workers along the northeast side of The Prow, indicate that the strata locally dip west; the reversal in dip appears to occur across small faults. The geologic map compiled by Maldonado (1985) shows a small northwest-trending graben cutting across this part of The Prow. The smaller fold at the end of West Crest is south of the area mapped by Scott and Bonk (1984) and is not shown on the regional geologic map of Swadley and others (1984).

Slump blocks and landslide deposits were mapped at a number of places. Notable among them is a large slump block that appears to be present along the northwest side of Fran Ridge. The block, outlined by faults that dip west into Midway Valley, appears to have covered the surface trace of the Paintbrush Canyon fault. Smaller slump blocks are also present on the east flank of Busted Butte, in Fortymile Wash, and in bedrock in the northwest corner of the map area. 


\section{SUMMARY AND INTERPRETATION OF PHOTOGEOLOGIC LINEAMENTS}

The Windy Wash fault appears to be a major fault in the southern Yucca Mountain area, but splits into at least three segments in the map area: the west splay (www) appears to die out northward; the central splay (wwc) continues northward, across the eastern part of Crater Flat, joining the main range-front fault in the upper reaches of Windy Wash; the east splay (wwe) appears to tectonically link the Windy Wash structure to the Solitario Canyon fault.

The Solitario Canyon fault is the main fault along the west side of Yucca Crest. This feature is a throughgoing structure that shows a complex, scissors-style displacement; it is down-to-thewest in the south and down-to-the-east in the north. The fault cuts across the northwest-trending ridges and valleys in the north central part of the map area and was interpreted by Christiansen and Lipman (1965) to cross the northwest-trending Yucca Wash and connect with a major eastdipping fault to the north. The fault splits into several splays on the south. The west splay is the same as the east splay of the Windy Wash fault (wwe); the central splay (ssc) may continue south from West Crest as a weak structure that dies out southward near the Stagecoach Road fault; the fault includes a third eastern splay (sce). Scott and Bonk (1984) mapped a series of small faul s that cut across the low ridge between Yucca Crest and West Crest; these faults may connect the Solitario Canyon fault with the fault that bounds the west side of Middle Crest--a connection that was not evident on the aerial photographs used in this study.

The traces of the Windy Wash and Solitario Canyon faults are locally unique in that they consist of en echelon, left-stepping fault scarps that are structurally linked. Both faults have segments connected across rhomboid-shaped zones that are characterized by northwest-trending fractures and (or) chaotic disruption of formerly smooth surfaces capped by colluvium (pl. 1; fig. 2) that appear to represent pull-apart grabens. The presence of such grabens requires that displacement on the Windy Wash and Solitario Canyon faults includes a component of strike-slip; the sense of overlap between the normal faults that define the rhomboid-shaped disturbed zones indicates that strike-slip movement is left-lateral (compare figs. $2 \mathrm{~b}$ and 3 ).

The Ghost Dance fault appears to be a minor structure that cuts across the eastern part of Yucca Crest. It terminates on the north against the northwest-trending Drill Hole Wash. To the south, the fault may be represented by several faults that displace rocks on Middle Crest and East Crest.

The Bow Ridge fault is the most difficult fault to recognize on the aerial photographs used in this study. This fault appears to terminate on the north in Midway Valley; the south end of the fault may curve southeast and join with the Paintbrush Canyon fault, as suggested by Scott and Bonk (1984).

The Paintbrush Canyon fault marks the eastern structural boundary of Midway Valley. In the northern part of the map area, the fault is not recognizable as a throughgoing structure on the aerial photographs, possibly due to the influence of the southern flank of the Timber Mountain caldera complex; on the south, the fault may curve southwest toward the Stagecoach Road fault, and (or) it may continue directly south where it is represented by the unique, reverse fault that cuts across the crest of Busted Butie.

The Stagecoach Road fault is not well defined on aerial photographs. It is represented by a major fault to the south that is colinear with subtle aerial photogeologic lineaments south of Busted Butte. 

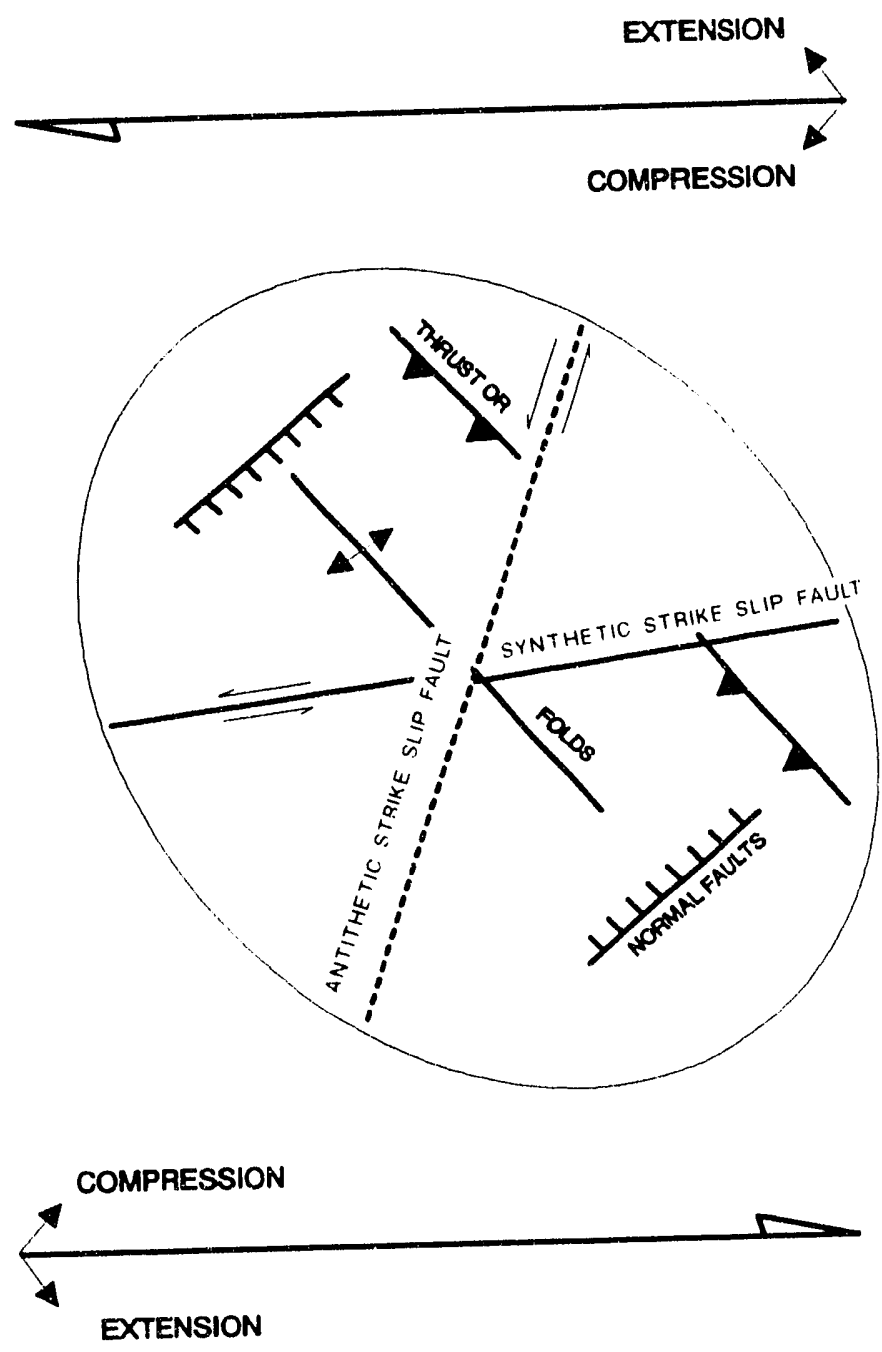

Figure 3.--The orientation of folds and faults expected in an area that has undergone left-lateral strike-slip faulting (modified from Harding, 1974). Orientation of normal faults agrees with small pull-apart grabens found along the Windy Wash and Solitario Canyon faults and with structural features in Midway Valley and vicinity. Orientation of folds agrees with possible compressional structures located along the southern part of Windy Wash fault and on East Crest. 
The series of northwest-trending valleys and ridges in the north-central part of the map area are unique in their orientation. Small faults and lineaments of possible structural origin are associated with several of these topographic features, suggesting that the topographic grain in this area is structurally controlled; however, major normal offset of volcanic rocks along northwesttrending structures is not present. Scott and Bonk (1984) mapped several faults in this area and interpreted them to be right-lateral strike-slip faults; this kinematic interpretation was based on a dextral component of oblique slip (R.B. Scott, USGS, oral commun., 1991) and the parallelism of the faults with the right-lateral Las Vegas shear zone to the southeast. Slickenlines on northwesttrending faults in this area plunge gently southeast (Scott and Bonk, 1984) indicating movement was oblique.

A striking geometric and structural similarity exists between the small pull-apart grabens along left-stepping faults in the western part of the map area and the topographic and structural configuration of ridges and valleys and associated faults and fractures in the north-central part of the map area. The area bounded by Yucca Wash on the north, the down-to-the-east segment of the Solitario Canyon fault on the west, the down-to-the-west Bow Ridge fault on the east, and the probable fault along Drill Hole Wash on the south, outline a large rhomboid-shaped structural depression (pl. 1). The Bow Ridge fault terminates against Yucca Wash on the north; the northern part of this fault appears to step left and connect with the Solitario Canyon fault via probable northwest-trending faults in Drill Hole Wash and in the central part of Yucca Wash. The dominant northwest-trending topographic and structural grain within this down-dropped area may be a reflection of pervasive tension fractures and normal faults associated with a component of left-lateral displacement along the north-trending Solitario Canyon and Bow Ridge fault systems (fig. 3).

Yucca Wash, the largest of the northwest-trending valleys, was interpreted by Scott and Bonk (1984) and Scott (1990) to be the locus of a concealed right-lateral strike-slip fault. Previous geologic maps of this area (Christiansen and Lipman, 1965; Byers and others, 1976) do not show any northwest-trending faults concealed beneath the Yucca Wash alluvium. The southern structural rim of the partly preserved Claim Canyon cauldron appears to be concealed beneath the alluvium in the upper, widest segment of Yucca Wash (D.A. Sawyer, U.S. Geological Survey, oral commun., 1991; Byers and others, 1976). The narrow, central part of the wash is interpreted in this report to contain a southwest-dipping normal fault that connects the left-stepping Bow Ridge fault with the Solitario Canyon fault. The lower part of the wash in Midway Valley was interpreted by Christiansen and Lipman (1965) to contain an east-dipping normal fault which, in conjunction with the west-dipping Paintbrush Canyon fault, outlines a north-trending graben in the southern flank of the Timber Mountain caldera complex (Christiansen and Lipman, 1965, cross section C$\left.C^{\prime}\right)$; this graben may extend beneath Midway Valley. If Midway Valley is the southern extension of this graben, the geomorphic development of the valley floor may reflect the evolution of subsidence of this part of the depression. Two distinct geomorphic terranes are present in the valley, separated by numerous northwest-trending lineaments in and adjacent to Sever Wash (pl. 1): on the north, the valley floor is irregular and strongly to moderately dissected, characterized by numerous entrenched arroyos associated with the southeast-draining Yucca Wash; on the south, the valley floor is marked by the smooth surface of an extensive youthful alluvial fan composed of detritus derived mainly from the west. Thus, Midway Valley may be interpreted to consist of two structural blocks; the highest block on the north steps down to a lower block on the south. Erosion of older alluvium dominates the highest block, whereas deposition of young alluvium characterizes the lowest block, suggesting that the most recent subsidence of the graben in Midway Valley is on the south. Significant subsidence in the southern part of the valley is also suggested by faults that appear to outline a large slump block in the northwestern part of Fran Ridge that has slid into the valley bottom, opposite the toe of the alluvial fan (pl. 1). 
The north- to northeast-trending reverse faults that cut across Busted Butte and East Crest and the apparent synclinal folds at The Prow and the south end of the Solitario Canyon fault are anomalous in the Yucca Mountain area. These structures are indicative of localized compressional stresses being operative during mainly extensiona! normal faulting that dominates the Great Basin region. The trend of the reverse faults, in particular, is approximately perpendicular to the northwest-trending fracture system in the north-central part of the area and may represent the complementary minor compressional component of stress in an area undergoing left-lateral, oblique-slip deformation (fig. 3).

\section{FIELD EVIDENCE FOR STRIKE-SLIP FAULTING}

The Yucca Mountain area is structurally dominated by a series of north-trending normal faults, most of which show down-to-the-west displacement. This normal faulting is clearly a reflection of regional crustal extension of the southern Great Basin that began as early as middle Cenozoic time (Hamilton, 1988). A surprising consequence of the photogeologic lineament analysis was the suggestion of a minor, but seemingly pervasive component of left-lateral slip along the normal faults in the Yucca Mountain area. Consequently, field examination of selected faults was undertaken to document or disprove this apparent component of strike-slip movement. Fault zones examined in the field during this study were segments of the Paintbrush Canyon, Windy Wash, and Stagecoach Road faults.

\section{Slickenlines}

Paintbrush Canyon Fault. The Paintbrush Canyon normal fault is locally well exposed along the west side of Fran Ridge in the east-central part of the map area (pl. 1). The fault is a linear to slightly irregular brecciated zone about $4 \mathrm{~m}$ thick that dips mainly $60^{\circ}$ to $70^{\circ}$ westerly. Discrete fault surfaces within this zone contain lineations formed during fault movement, including slickenlines on polished surfaces, faint striations on unpolished surfaces, and mullion structures (fig. 4a). In the stereographic projections shown on figures $4 b$ and $4 c$, the orientation of 27 segments of this fault plane are plotted together with the azimuth and plunge of 30 linear slickenlines preserved along more than $300 \mathrm{~m}$ of this fault zone. These data indicate that there are two preferred fault-plane orientations striking N. $7^{\circ} \mathrm{E}$. and N. $17^{\circ} \mathrm{W}$. and dipping westerly $66^{\circ}$ and $57^{\circ}$, respectively. Slickenlines measured on these surfaces plunge, on average, $51^{\circ} \mathrm{S} .41^{\circ} \mathrm{W}$. indicating that movement along this fault segment was oblique; displacement was down-to-the-west and left-lateral. The mean slickenline direction is also parallel to the line of intersection of the two fault planes indicating that true slip on all fault segments was oblique.

The Paintbrush Canyon fault was also examined to the north, where it crosses Yucca Wash. Scott and Bonk (1984) recorded slickenlines plunging gently southwest in this area. Our measurements, confirming those of Scott and Bonk, show slickenlines plunging $39^{\circ}$ to $41^{\circ}$ southwest, indicating that left-lateral oblique-slip displacement occurred along the Paintbrush Canyon fault north of Yucca Wash.

Stagecoach Road Fault. The Stagecoach Road fault is well exposed in the extreme southcentral part of the map area (pl. 1), where it is marked by a zone of breccia, fractures, and abundant calcium carbonate that fills fractures and associated voids. The zone of brecciation and $\mathrm{CaCO}_{3}$ buildup can be traced south of the map area where the fault is also marked by small westfacing scarps that locally expose polished surfaces containing slickenlines. Figure $5 \mathrm{a}$ is a stereographic projection of three fault planes and associated slickenlines measured along fault segments south of the map area. The strike of the fault surfaces is north-northeast (fig. 5a). Slickenlines on all surfaces are inclined along an azimuth that trends south of the azimuth of the dip of the fault. A smail fault scarp exposed directly north of the old stagecoach road in the map area also contains well-developed slickenlines (fig. 6). This fault also dips westerly and contains 


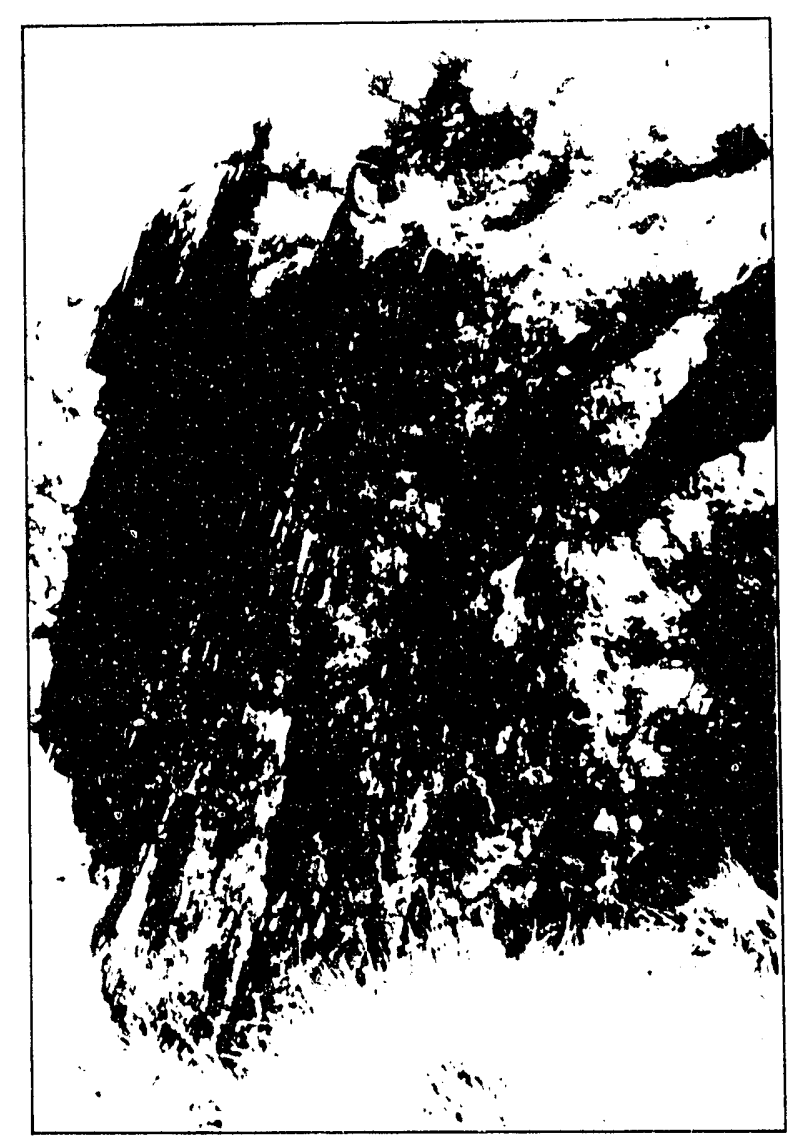

a

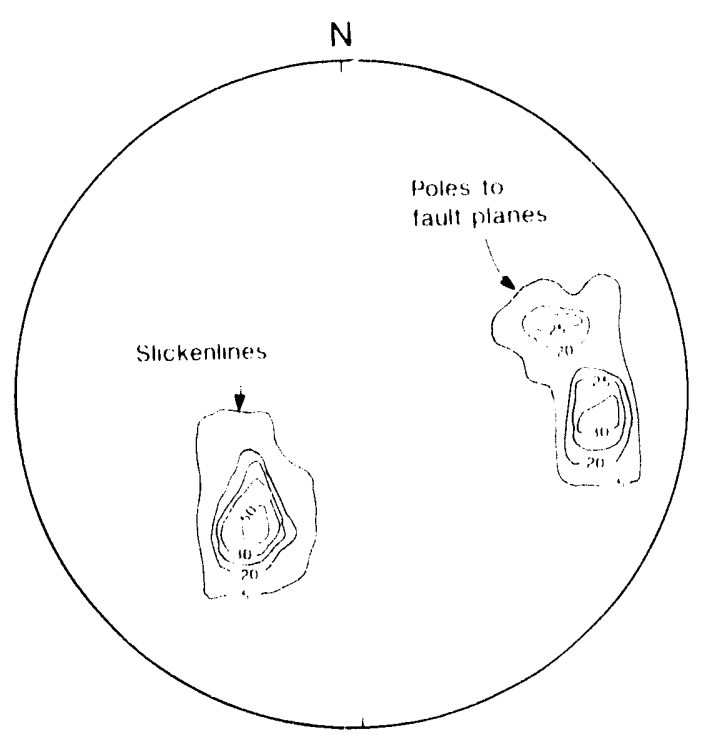

b

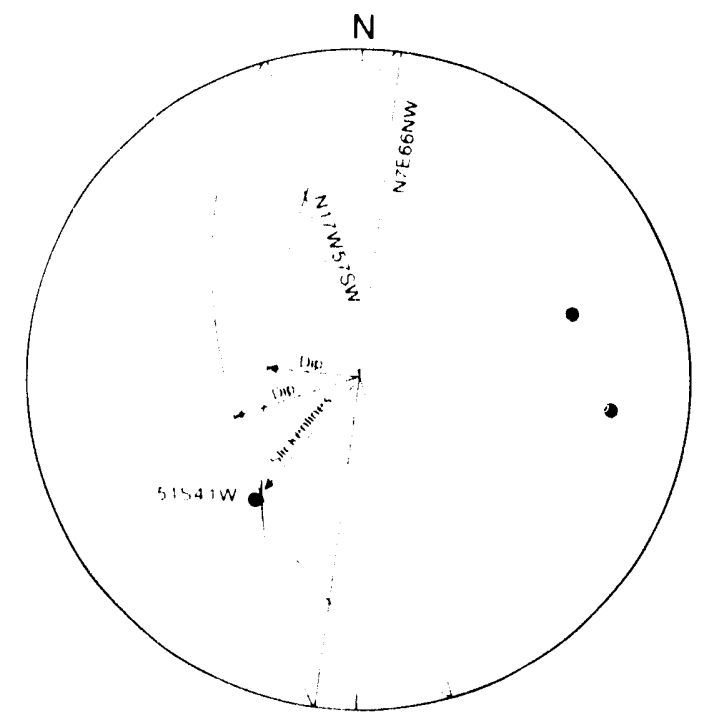

C

Figure 4.--(a) Paintbrush Canyon fault along west side of Fran Ridge showing southwesterly inclined slickenlines preserved on fault plane: rock hammer in center of photograph for scale (view to the north), (b) lower hemisphere equal-area projection showing a bipolar density of poles to fault plane segments along the Paintbrush Canyon fault in area of figure 4a (contours 5, 20, 25, and 30 percent), and the density of azimuth and plunge of slickenlines preserved on these fault planes (contours 5, 20, 25, 30, and 50 percent); (c) lower hemisphere, equal area projection showing the two preferred orientations of fault planes determined from figure $4 \mathrm{~b}$ and the preferred orientation of slickenlines, common to all f.ults in this area, which plots at the intersection of the two fault planes. 

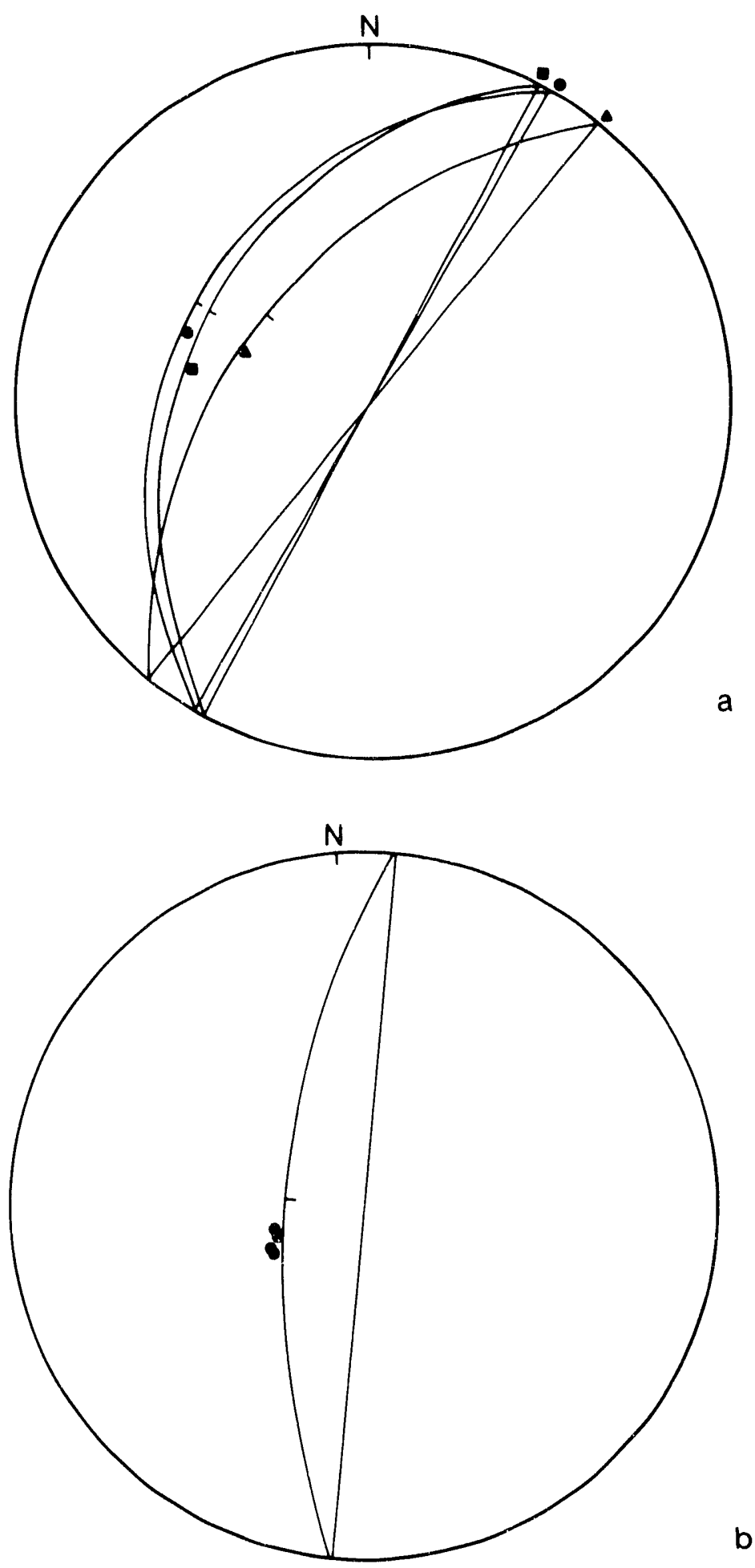

Figure 5.--(a) Lower hemisphere stereographic projection showing orientation of three segments of the Stagecoach Road fault and the azimuth and plunge of slickenlines on showing of the lower hemisphere stereographic projection showing orientation of a probable splay of the Stagecoach Road fault exposed north
slickenlines preserved on fault plane. 


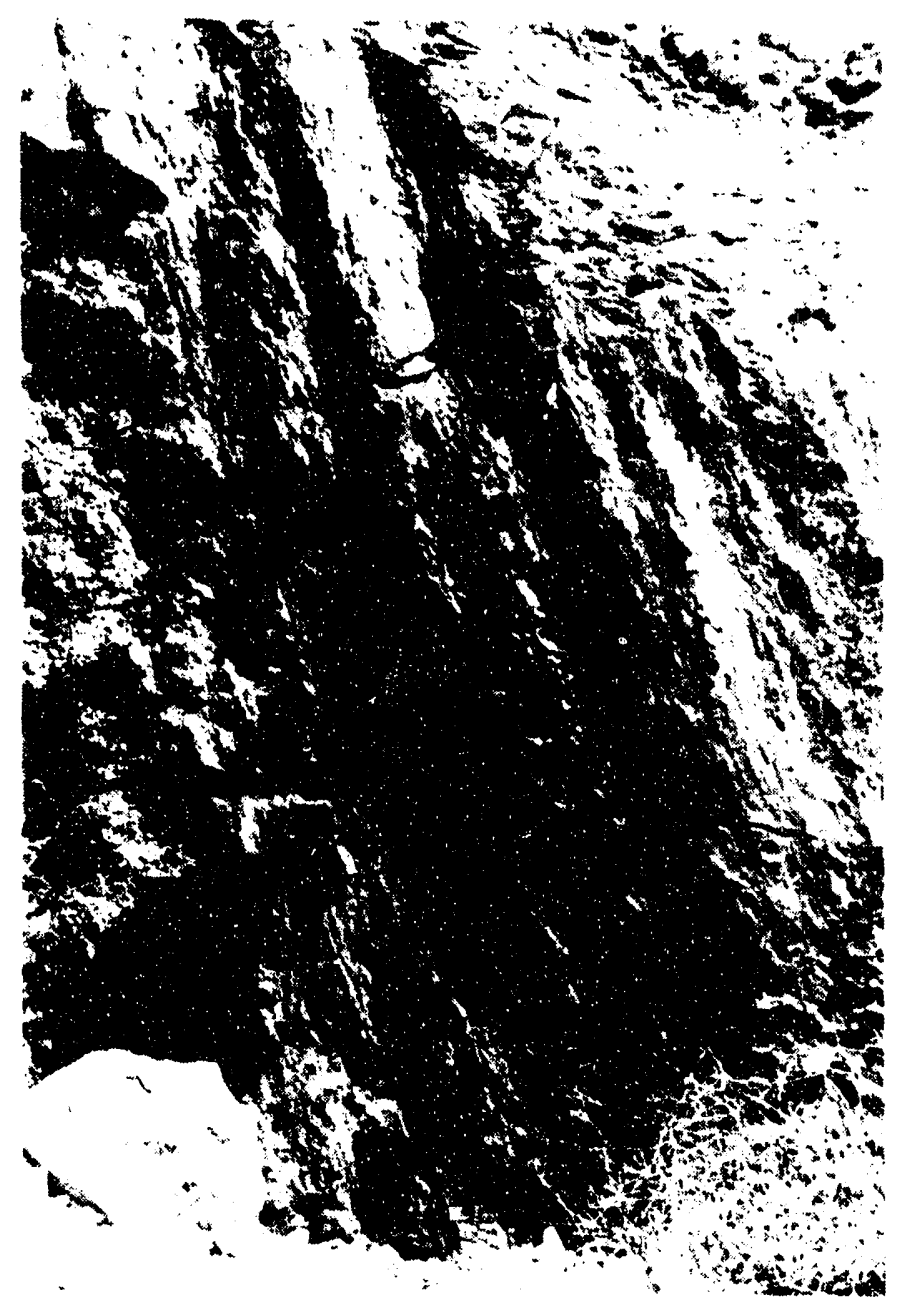

Figure 6.--Probable splay of Stagecoach Road fault (view to south). Orientation of fault plane and of well-developed slickenlines on this fault surface are shown on figure $5 \mathrm{~b}$. 
lineations that are inclined along an azimuth that trends south of the azimuth of the dip of the fault (fig. 5b). Geometric relationships between fault dip and orientation of slickenlines along these fault segments--that is, the plunge of the slickenlines is less steeply inclined and the azimuth of these lines is south of the azimuth of the dip of the fault-are everywhere similar to those observed along the Paintbrush Canyon fault (fig. 4c), and indicate oblique-slip with a component of left-lateral displacement. These slickenlines plunge more steeply than those measured along the Paintbrush Canyon fault, and most likely indicate that the dip-slip component of oblique movement along the Stagecoach Road fault in the south is greater than that for the Paintbrush Canyon fault to the northeast. This interpretation conforms with Scott's (1990, p. 269) conclusion that the degree of extension increases southward across Yucca Mountain.

Windy Wash Fault. Slickenlines were observed in two locations along the Windy Wash fault. Rare slickenlines are preserved along fault splays filled with calcium carbonate and exposed in trenches dug across the fault (at ww1, pl. 1) in the southwest corner of the map area (Marith Reheis, U.S. Geological Survey, oral commun., 1991). Two orientations of intersecting slickenlines are preserved; both plunge southwest at an acute angle to the dip of the fault plane. Polished surfaces containing slickenlines are also exposed along the fault, about $400 \mathrm{~m}$ north of the pullapart graben (ww2, pl. 1 and fig. 1). In this area, this northwest-dipping fault contains slickenlines that plunge $43^{\circ}$ to $47^{\circ}$ southwest, indicating a component of left-lateral slip.

\section{En Echelon Fault Segments}

The rhomboid-shaped disturbed zone (ww2) that appears to be a pull-apart graben between left-stepping en echelon fault segments on the northern part of the Windy Wash fault was examined in the field. The fault segment on the south clearly steps left, across a disturbed zone, and then continues northward a short distance before it again steps left (fig. 2a,b). The larger, southern disturbed zone consists of a series of structural, northwest-trending terraces that decrease in elevation from northeast to southwest, defining a structural sag across a formerly continuous, smooth colluvial slope (figs. $2 \mathrm{a}$ and 7 ).

The pattern of left-stepping, en echelon fault segments observed on aerial photographs (pl. 1) can also bu observed at a smaller scale in the field along both the Paintbrush Canyon (fig. 8a) and Windy Wash faults. Both faults, where examined in the field, are marked by brecciated zones about $4-5 \mathrm{~m}$ thick. Small north-trending fault scarps within the breccia zones commonly step left several meters in an en echelon pattern (fig. 8a); the scarps are commonly not connected by a single northwest-trending break or fracture, but rather by a zone of rubble and breccia. The two principal fault planes statistically defined from field measurements and shown in the stereographic projection of figure $4 \mathrm{c}$ graphically depict the preferred orientation of slip surfaces that were active along left-stepping fault zones.

In the southwestern part of the map area, field examination revealed subtle surface offsets that indicate that the northern part of Windy Wash fault splay www shows scissors-type displacement: down-to-the-west on the south and down-to-the-east on the north. South of this reversal in sense of displacement is an oblong wedge of elevated alluvium (ww1) that is bounded on the east and west by normal fault segments. The Quaternary alluvium (Whitney and others, 1986 ) within this wedge appears to be deformed into folds that trend N. $25-40^{\circ} \mathrm{E}$. The dashed line on figure $8 \mathrm{~b}$ is drawn at the base of a coarse, locally calcite-cemented, alluvial gravel present below soils developed on the surface. This layer of older alluvial gravel appears to be continuous across the exposure, defining an open, northeast-trending fold. Rare slickenlines in calcite-filled fractures in the fault zone on the west side of the wedge plunge gently to steeply southwest indicating a component of left-lateral slip. The apparent folding of surficial deposits in this wedge, the structural elevation of the wedge above the surrounding terrain, and the association of the wedge 

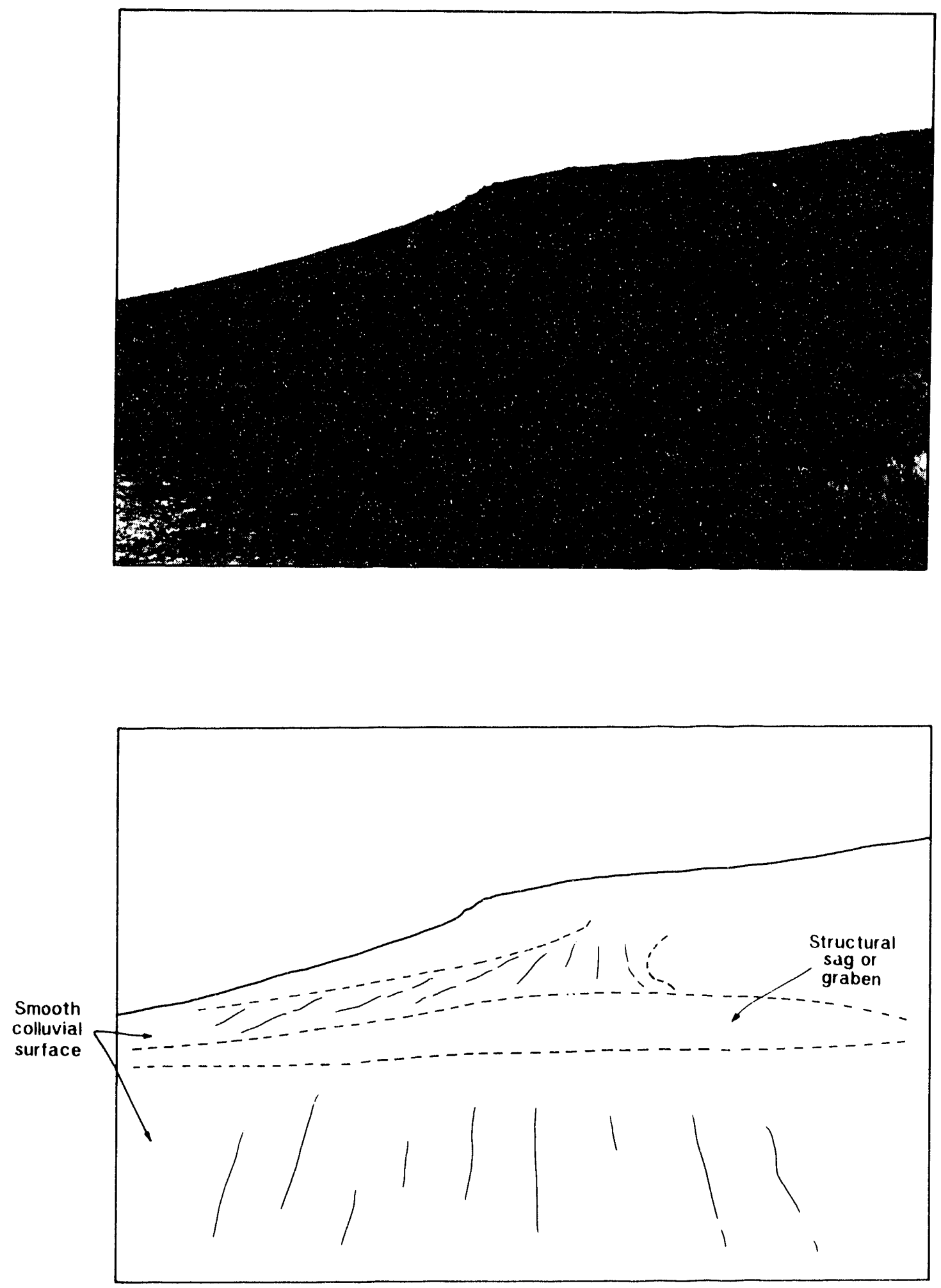

Figure 7.--Smooth colluvial slope disrupted by the larger pull-apart graben shown on figure 2 along the Windy Wash fault (view to northeast, up the colluvial slope). 


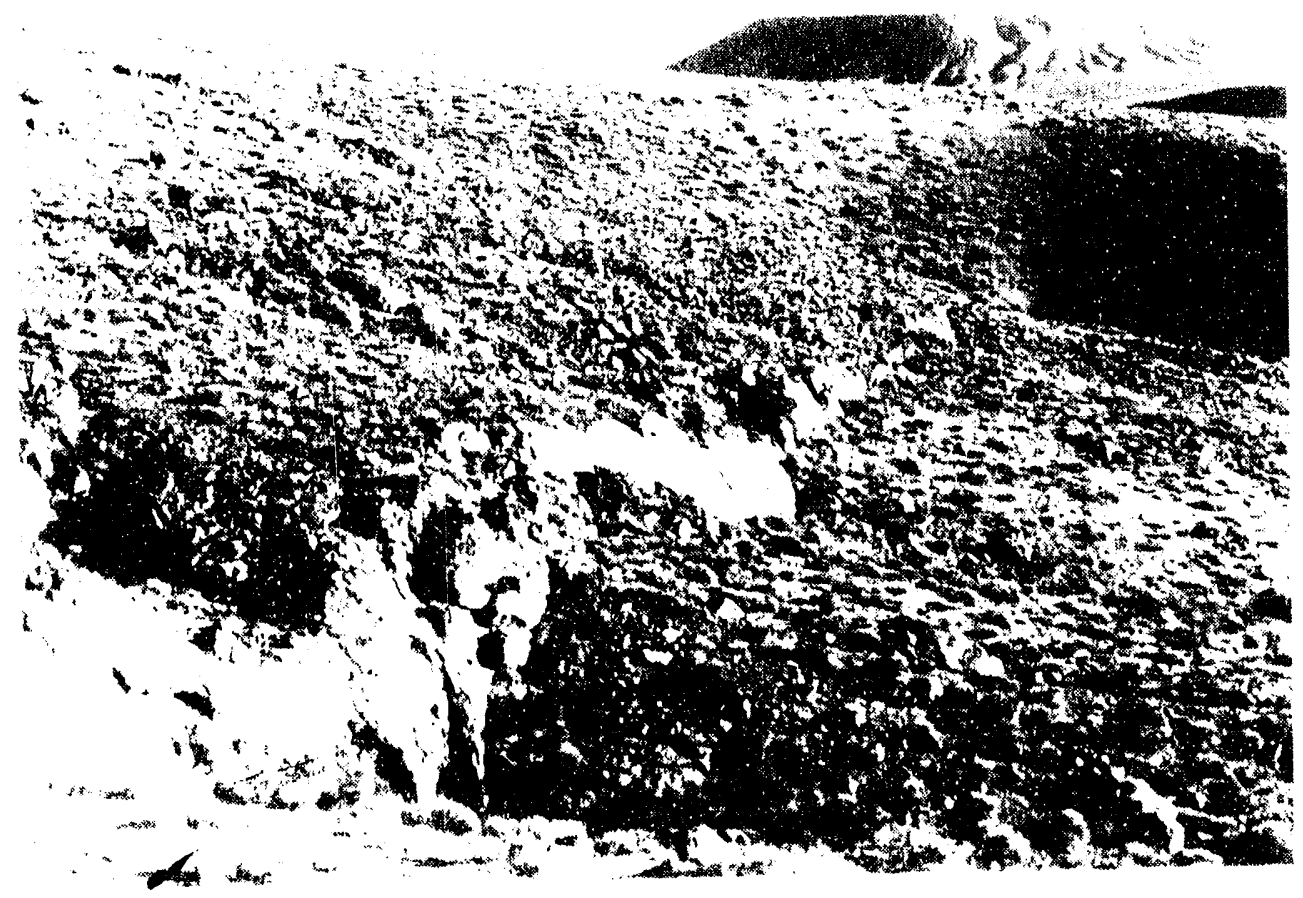

a

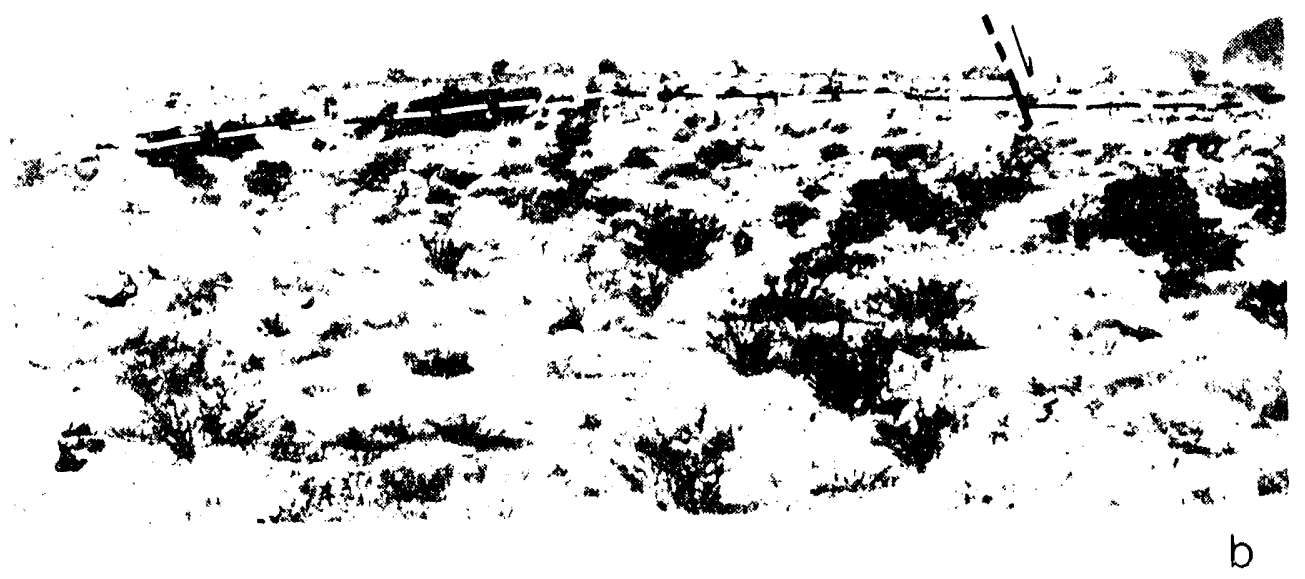

Figure 8.--(a) Paintbrush Canyon fault along the west side of Fran Ridge showing the left-stepping, en echelon outcrop pattern of fault segments (view to south; Busted Butte in hackground); (b) apparent fold in Quaternary-Tertiary alluvium in wedge-shaped area (ww 1, pl. 1) along the Windy Wash fault (view to west). Dashed line follows bedding 
with oblique-slip faults that show scissors-type displacement, suggests that complex forces were operating during deformation. Such forces cannot be manifested during simple extension and normal faulting, but require some component of strike-slip displacement; the northeast trend of these possible compressional features is an expected orientation for folds developed in an area that has undergone left-lateral strike-slip faulting (fig. 3).

\section{Ofiset Stream Channels}

Some stream channels in the Yucca Mountain area are offset in a left-lateral manner where they cross known north- to northeast-trending fault scarps. These offset channels are characterized by a distinctive morphology, schematically shown on figure 9. Characteristically, the main channel above the scarp is narrow, v-shaped, cut into bedrock, and trends directly downslope to the fault scarp. Directly below the scarp, the channel, in plan view, is broad and triangularshaped; the northern bank of the broad channel is commonly a levee composed of coarse debris deposited on the downthrown side of the fault scarp. The levee curves toward the downstream continuation of the main v-shaped channel that is parallel to but offset from the channel above the scarp, and joins the channel at an acute angle. The size of the triangular zone below the fault scarp is variable and is directly proportional to the amount of apparent lateral offset of the main stream channel; recognizable left offset of stream channels ranges from about $1.5 \mathrm{~m}$ to $4 \mathrm{~m}$. At several localities there is a subdued, young channel above the fault scarp that is continuous with the main, offset channel below the fault scarp. The young channel is formed by headward erosion of the offset channel, is less incised than the original main channel, and extends only a few tens of meters up slope. Offset stream channels are locally present along the Windy Wash, Paintbrush Canyon, and Stagecoach Road faults where they are associated with pull-apart grabens, inclined slickenlines, and en echelon fault segments.

\section{PALEOMAGNETIC EVIDENCE FOR OROCLINAL BENDING AT YUCCA MOUNTAIN AND IMPLICATIONS FOR LEFT-LATERAL STRIKE-SLIP FAULTING}

Paleomagnetic data from well dated, late Miocene ash-flow tuffs at Yucca Mountain show marked differences in declination of paleomagnetic remanence directions from one locality to another (Rosenbaum and others, 1991). These differences in declination suggest that the southern part of Yucca Mountain has been rotated with respect to the northern part since about $13 \mathrm{Ma}$; the rotation is clockwise about a vertical axis and increases systematically from north to south to a maximum rotation of $30^{\circ}$ in the southern part of Yucca Mountain.

The field investigations of Scott and Bonk (1984) and the photogeologic data gathered during this study suggest that the linear ridges that compose most of the Yucca Mountain area are not strongly broken or internally deformed; rather they are best described as rigid fault blocks. The consistent tilt of these individual blocks to the east (rotation about horizontal axes) and their clockwise rotation about a vertical axis (oroclinal bending of crustal fragments) suggest that deformation occurred mainly along faults and fractures between the blocks. The kinematics of large vertical-axis block rotations, as proposed by McKenzie and Jackson (1986) and Nur and others (1986), involves strike-slip deformation along faults between rigid fault blocks. Clockwise, vertical-axis rotation of the "domino-style" fault blocks of the Yucca Mountain area, modeled in figure 10, necessarily involves left-lateral strike-slip movement along intervening faults. We interpret the left-lateral component of slip along most north- to northeast-trending faults at Yucca Mountain, as indicated by pull-apart grabens, southwesterly inclined slickenlines on fault surfaces, the pattern and character of en echelon fault segments, and offset stream gullies, to have occurred in response to clockwise oroclinal bending of rigid crustal blocks. Evidence for oblique slip on faults at Yucca Mountain suggests that most fault blocks underwent a single, continuous rotation about inclined axes rather than two separate rotations about horizontal and vertical axes. 


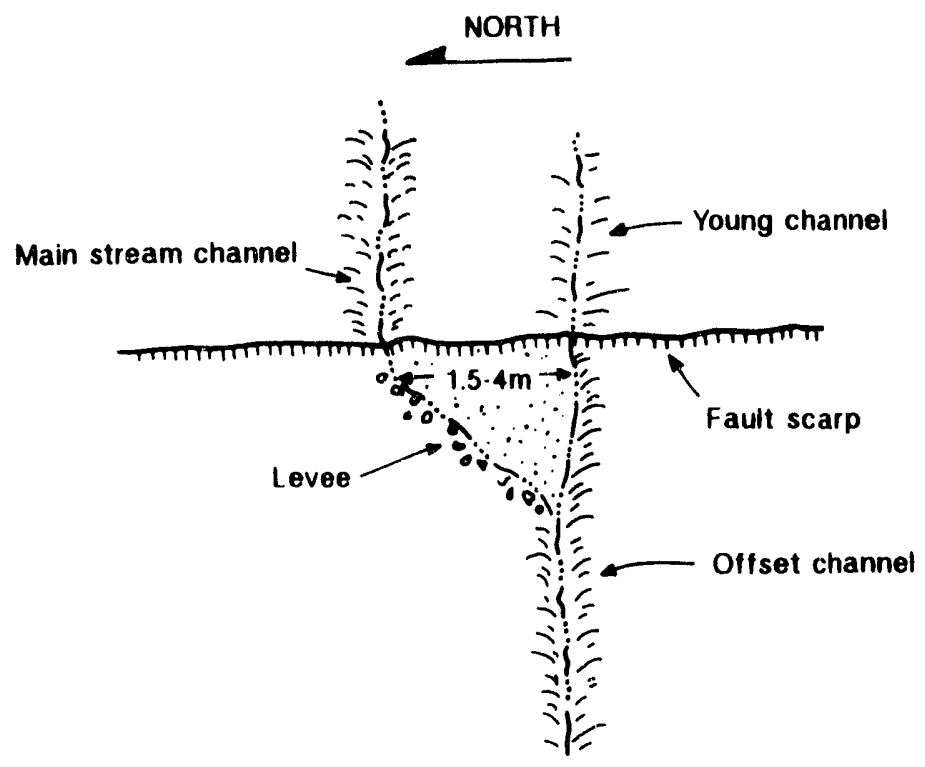

Figure 9.--Schematic diagram showing idealized morphology of stream channels offset in a leftlateral sense across fault scarps.

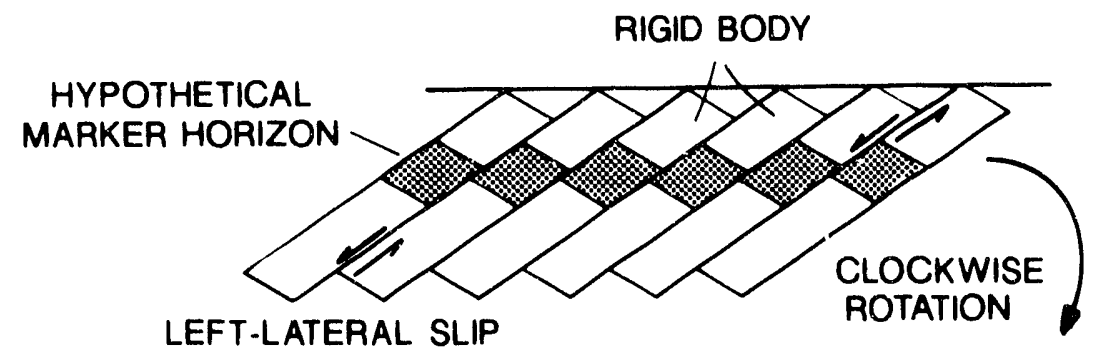

Figure 10.--Block model showing clockwise block rotation and left-lateral strike-slip faulting during rigid body deformation (modified from Nur and others, 1986). 
Clockwise oroclinal bending of southern Yucca Mountain may reflect right-lateral shear above a discrete, buried right-lateral strike-slip fault; the right-lateral Las Vegas shear zone trends toward Yucca Mountain but seems to end southeast of this area. Alternatively, the rotation may reflect a shear gradient set up by differential extension between little-extended northern Yucca Mountain and the highly extended Death Valley region directly to the south. Left-lateral components of displacement on north-trending as well as northwest-trending faults at Yucca Mountain would have acted to accommodate clockwise rotation in rocks resting above a broad zone of right-lateral shear.

\section{ACKNOWLEDGMENTS}

This report benefited from careful reviews by Kenneth Fox, Virginia Glanzman, William Johnson, Richard Keefer, Karl Kellogg, and Marith Reheis, all members of the U.S. Geological Survey, Branch of Central Regional Geology. This study was performed in cooperation with the Nevada Operations Office, U.S. Department of Energy, Interagency Agreement DE-AI0878ET44802.

\section{REFERENCES CITED}

Byers, F.M., Jr., Carr, W.J., Christiansen, R.L., Lipman, P.W., Orkild, P.P., and Quinlivan, W.D., 1976, Geologic map of the Timber Mountain caldera area, Nye County, Nevada: U.S. Geological Survey Miscellaneous Investigations Series Map I-891, scale 1:48,000. (HQS.880517.1107)

Carr, W.J., 1984, Regional structural setting of Yucca Mountain, southwestern Nevada, and Late Cenozoic rates of tectonic activity in part of the southwestern Great Basin, Nevada and California: U.S. Geological Survey Open-File Report 84-854, 109 p. (NNA.870325.0475)

Christiansen, R.L., and Lipman, P.W., 1965, Geologic map of the Topopah Spring NW quadrangle, Nye County, Nevada: U.S. Geological Survey Geologic Quadrangle Map GQ-444, scale 1:24,000. (HQS.880517.1118)

Fox, K.F., Jr., and Carr, M.D., 1989, Neotectonics and volcanism at Yucca Mountain and vicinity, Nevada: Radioactive Waste Management and the Nuclear Fuel Cycle, v. 13 (1-4), p. 37-50. (NNA.900614.0534)

Fox, K.F. Jr., Spengler, R.W., and Myers, W.B., 1990, Geologic framework and Cenozoic evolution of the Yucca Mountain area, Nevada, in Sinha, R.S., ed., Proceedings, International Symposium on Unique Underground Structures, v. 2, p. 56-1 to 56-18. (NNA.910301.0011)

Frizzell, V.A., Jr., and Shulters, Jacqueline, 1990, Geologic map of the Nevada Test Site, southern Nevada: U.S. Geological Survey Miscellaneous Field Investigations Map I-2046, scale $1: 100,000$. (NNA.910123.0073)

Hamilton, W.B., 1988, Detachment faulting in the Death Valley region, California and Nevada, in Carr, M.D., and Yount, J.C., Investigations of the geological and geophysical characterization of a potential nuclear waste disposal site at Yucca Mountain, southern Nevada: U.S. Geological Survey Bulletin 1790, p. 51-86. (NNA.920211.0034)

Harding, T.P., 1974, Petroleum traps associated with wrench faults: American Association of Petroleum Geologists Bulletin, v. 58, p. 1290-1304. (NNA.920811.0104) 
Maldonado, Florian, Geologic map of the Jackass Flats area, Nye County, Nevada: U.S. Geological Survey Miscellaneous Investigations Series Map I-1519, scale 1:48,000. (HQS.880517.1925)

McKenzie, D.P., and Jackson, J.A., 1986, A block model of distributed deformation by faulting: Journal of the Geological Society, London, v. 143, p. 349-353. (NNA.920811.0105)

Nur, Amos, Hagai, Ron, and Oona, Scotti, 1986, Fault mechanics and the kinematics of block rotations: Geology, v. 14, p. 746-749. (NNA.920811.0106)

Reheis, M.C., and Noller, J.S., in press, Aerial photographic interpretation of lineaments and faults in Late Cenozoic deposits in the eastern part of the Benton Range 1:100,000 quadrangle and the Goldfield, Last Chance Range, Beatty, and Death Valley Junction 1:100,000 quadrangles, Nevada and California: U.S. Geological Survey Open-File Report 90-41, scale 1:100,000. (NNA.901031.0001)

Rosenbaum, J.G., Hudson, M.R., and Scott, R.B., 1991, Paleomagnetic consiraints on the geometry and timing of deformation at Yucca Mountain, Nevada: Journal of Geophysical Research, $v$. 96, no. B2, p. 1963-1979. (NNA.911220.0074)

Scott, R.B., 1990, Tectonic setting of Yucca Mountain, southwest Nevada, in Wernicke, B.P., ed., Basin and Range extensional tectonics near the latitude of Las Vegas, Nevada: Geological Society of America Memoir 176, p. 251-282. (NNA.920131.0325)

Scott, R.B., and Bonk, Jerry, 1984, Preliminary geologic map of Yucca Mountain, Nye County, Nevada, with geologic sections: U.S. Geological Survey Open-File Report 84-494, scale 1:12,000. (HQS.880517.1443)

Swadley, W C, Hoover, D.L., and Rosholt, J.N., 1984, Preliminary report on late Cenozoic faulting and stratigraphy in the vicinity of Yucca Mountain, Nye County, Nevada: U.S. Geological Survey Open-File Report 84-788, 42 p. (HQS.880517.1515)

Whitney, J.W., Shroba, R.R., Simonds, F.W., and Harding, S.T., 1986, Recurrent Quaternary movement on the Windy Wash fault, Nye County, Nevada [abs]: Geological Society of America Abstracts with Programs, v. 18, no. 67, p. 787. (NNA.920811.0107)

Note: Parenthesized numbers following each cited reference are for U.S. Department of Energy, Office of Civilian Radioactive Waste Management purposes only and should not be used when ordering the publication. 
The following nuinber is for U.S. Department of Energy Office of Civilian Radioactive Waste Management records management purposes only, and should not be used when ordering this publication: Accession number--NNA.921211.0174.

*U.S. GOVERNMENT PRINTING OFFICE: 1993-775-091 


\section{U.S. DEPARTMENT OF INTERIOR U.S. GEOL.OGICAL SURVEY}

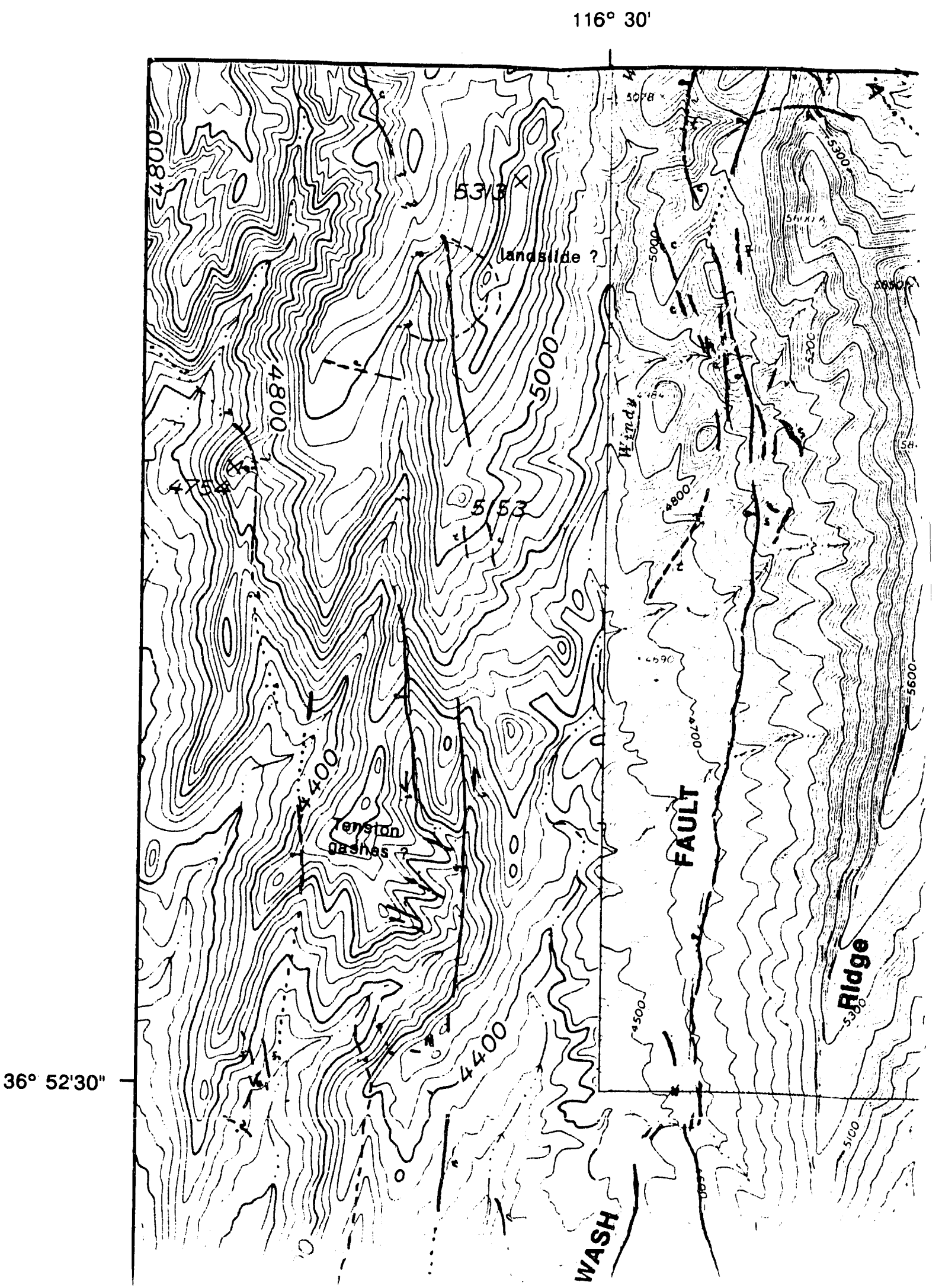




\section{Prepared in cooperation with}

the U.S. Department of Energy

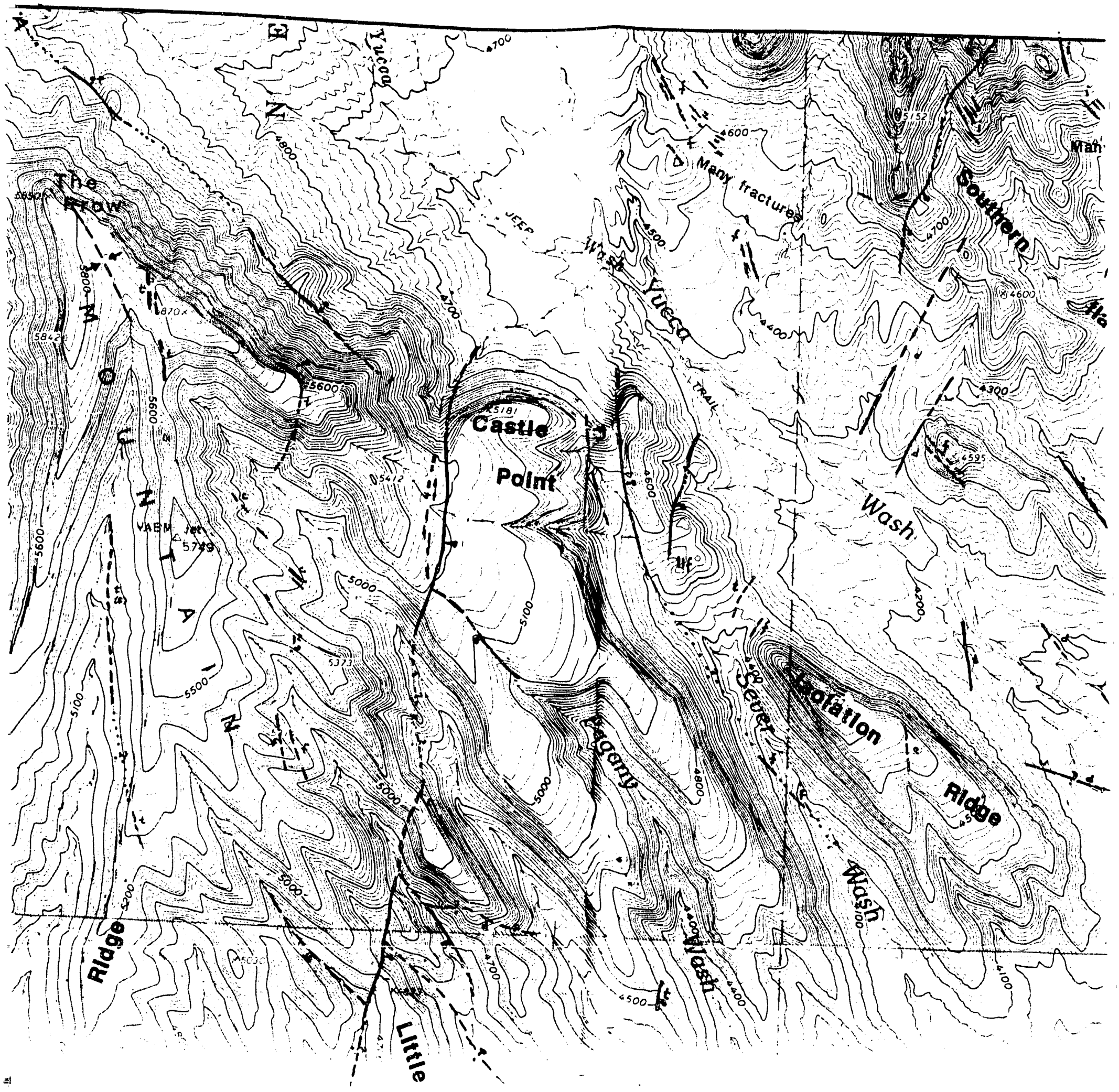


Open-File Report

91-623

Plate 1

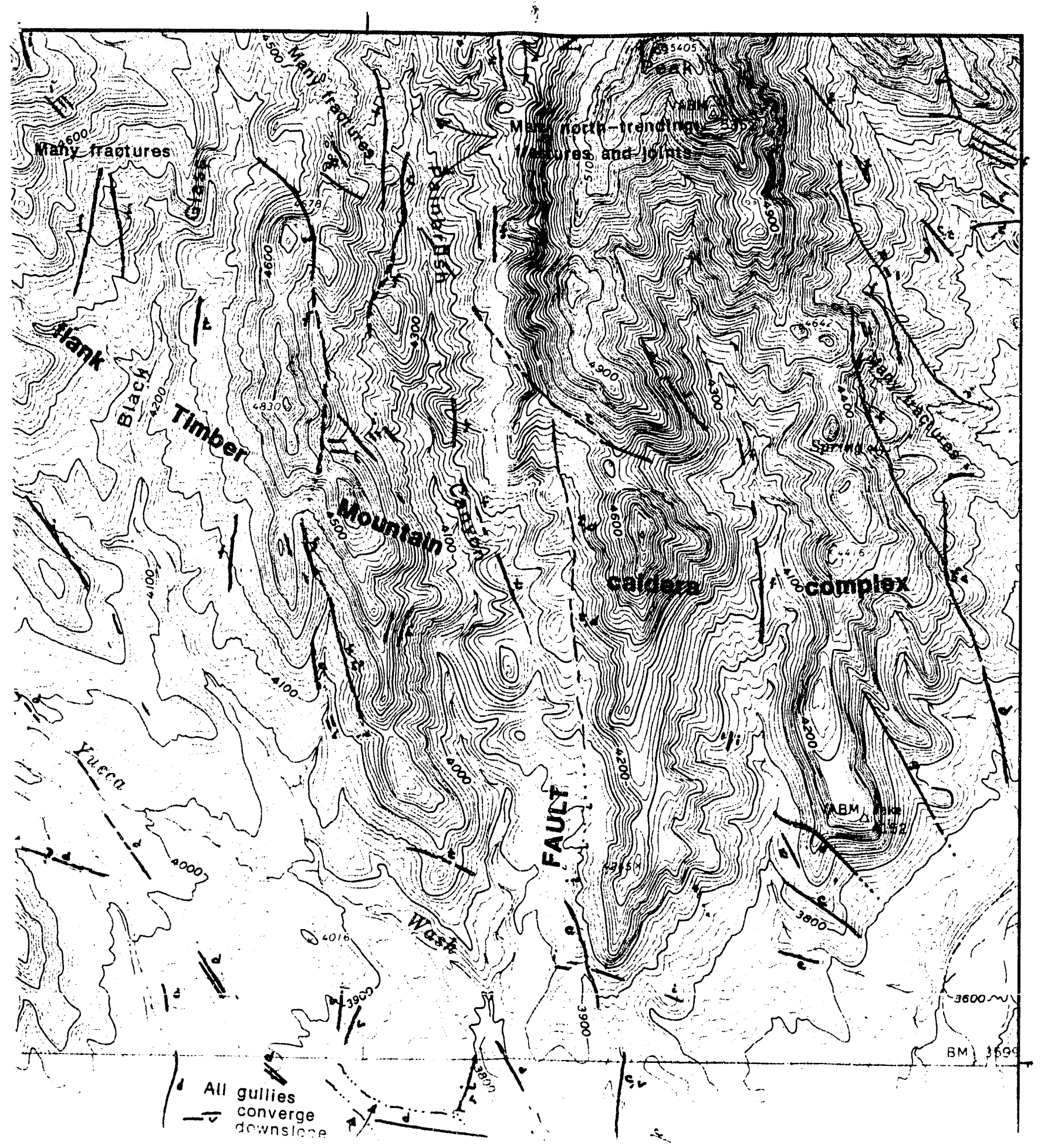




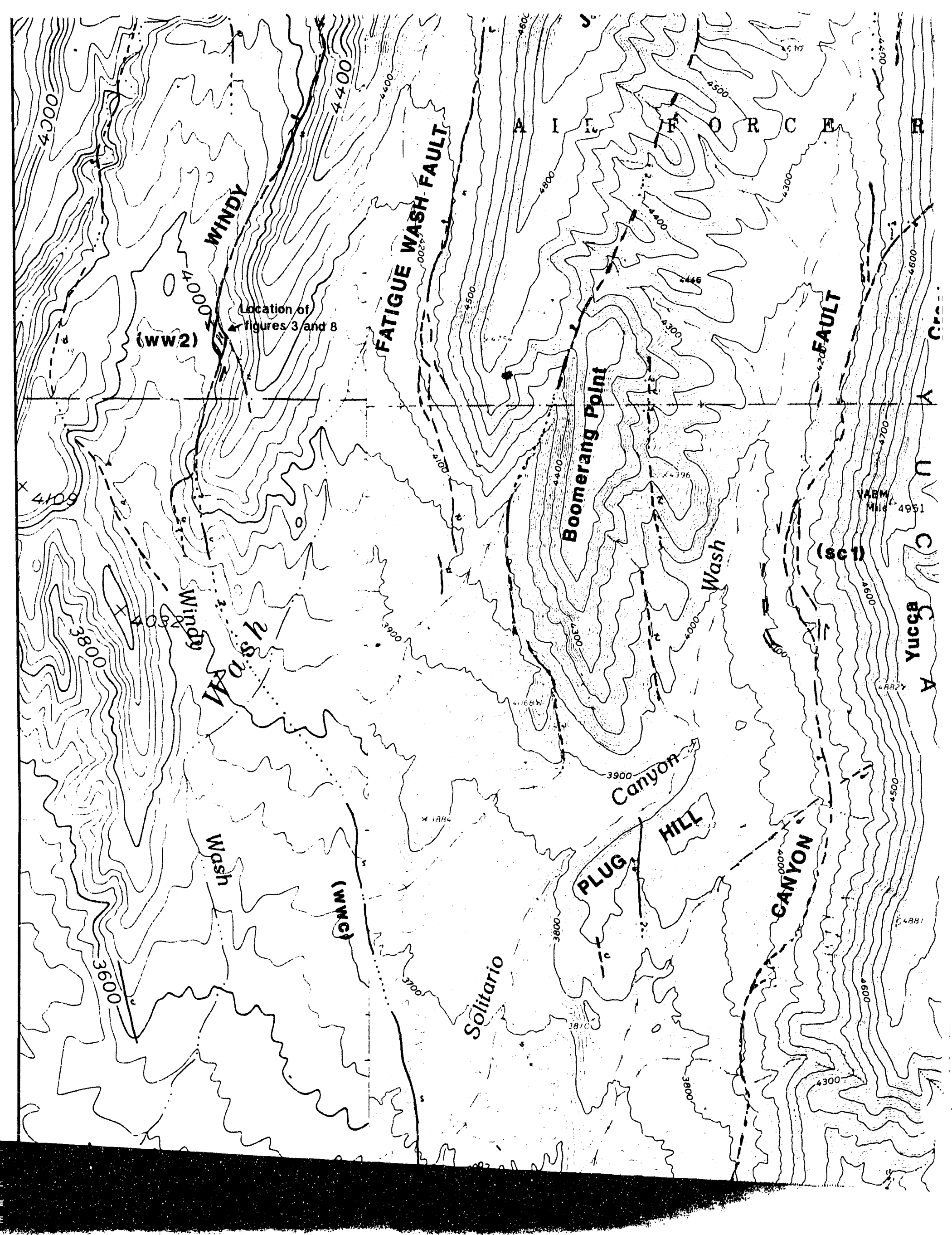




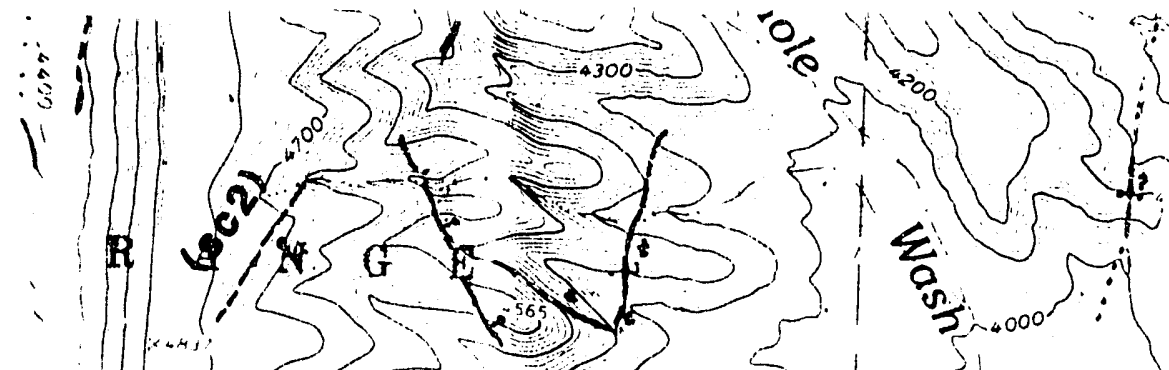

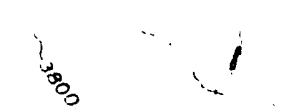




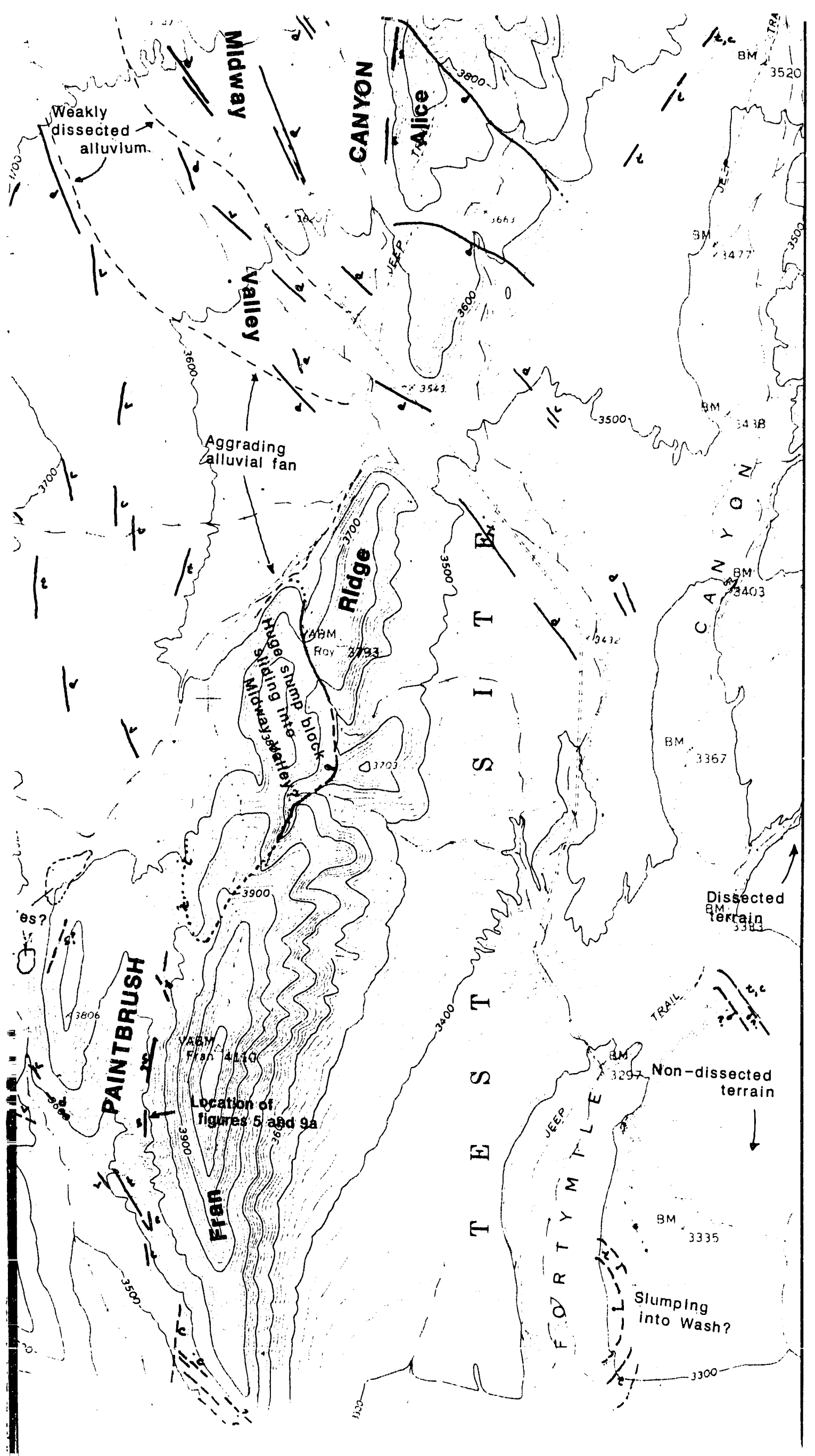




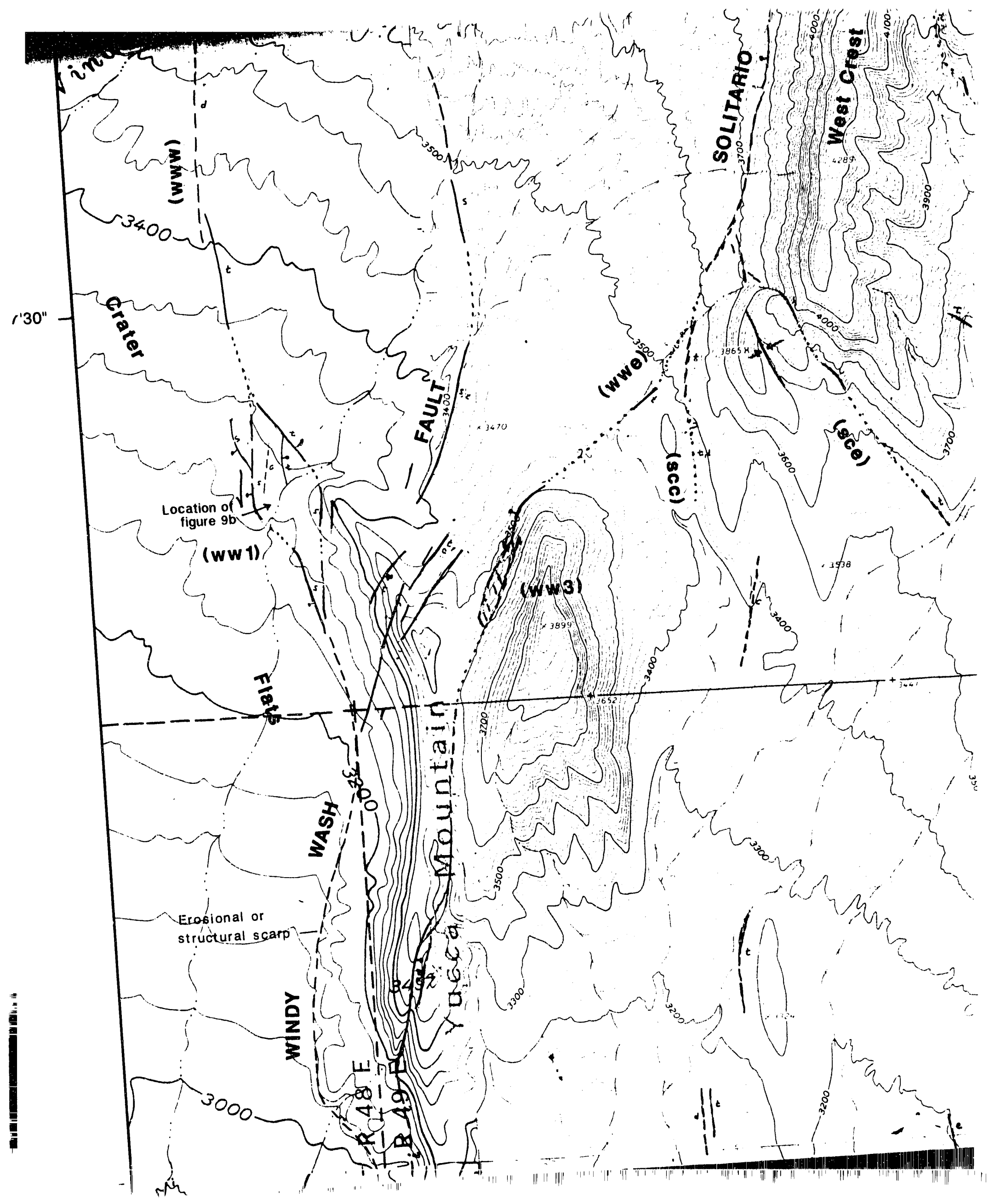




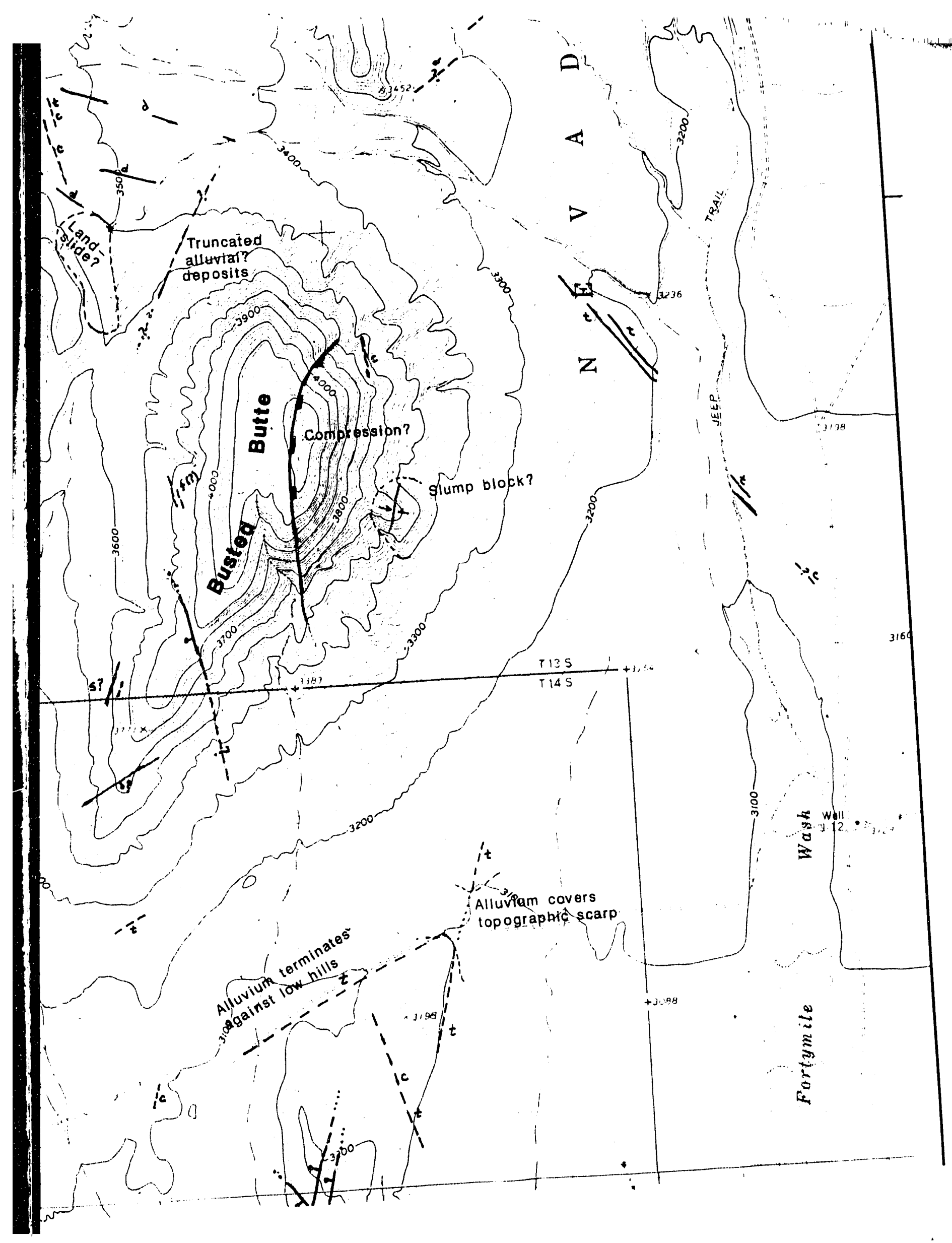



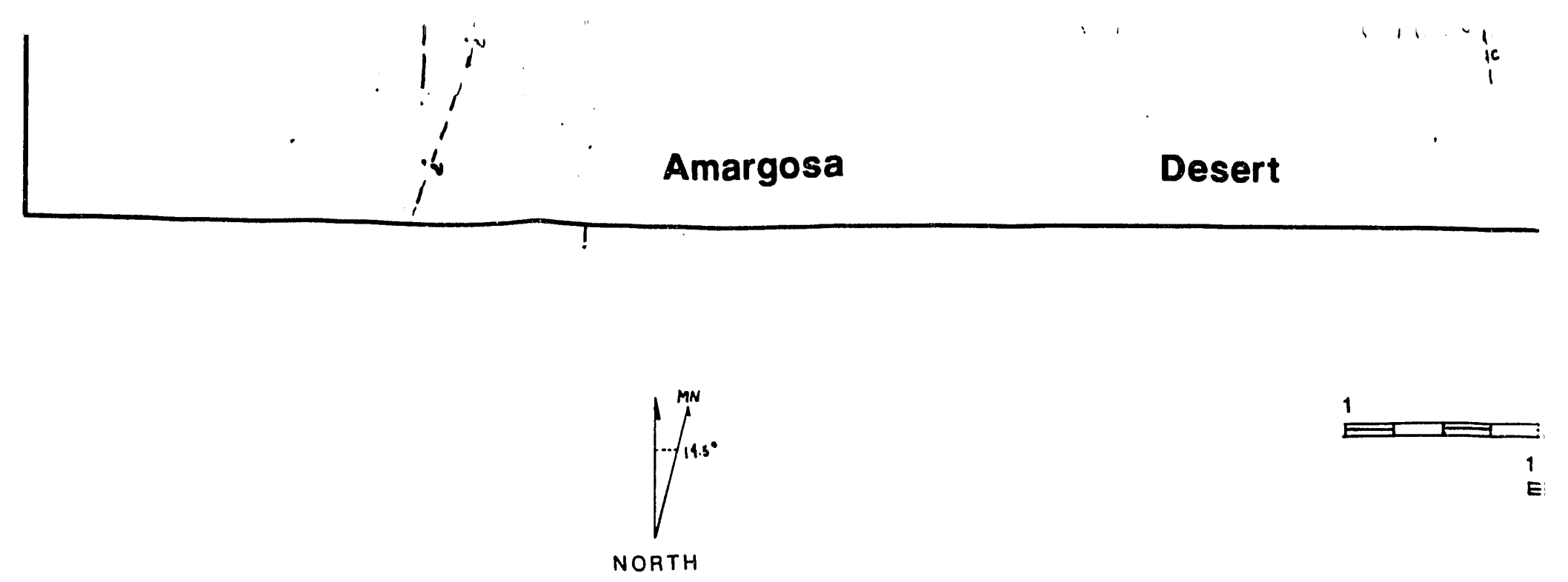

Photogeologic lineament map of Yucı

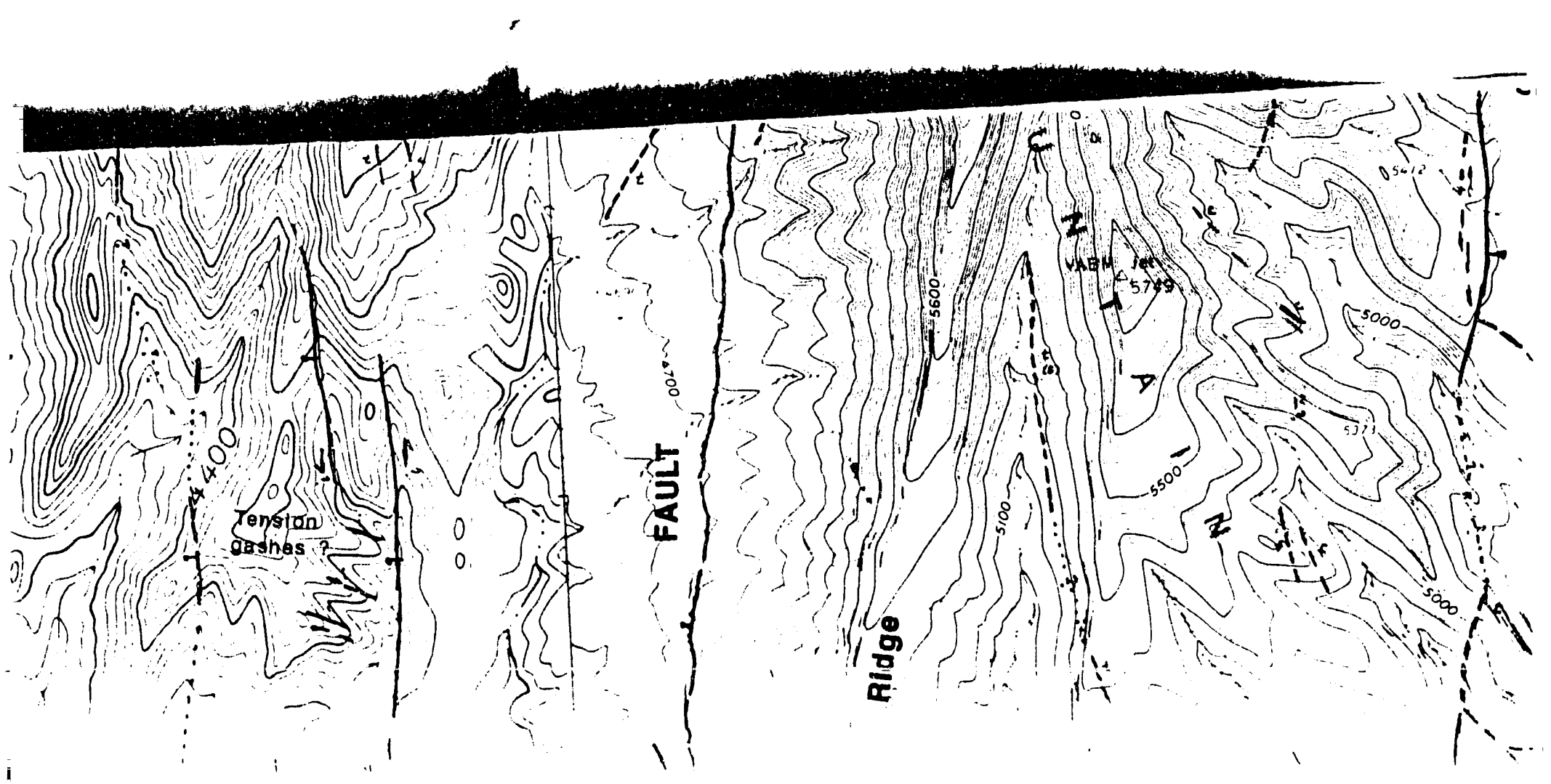




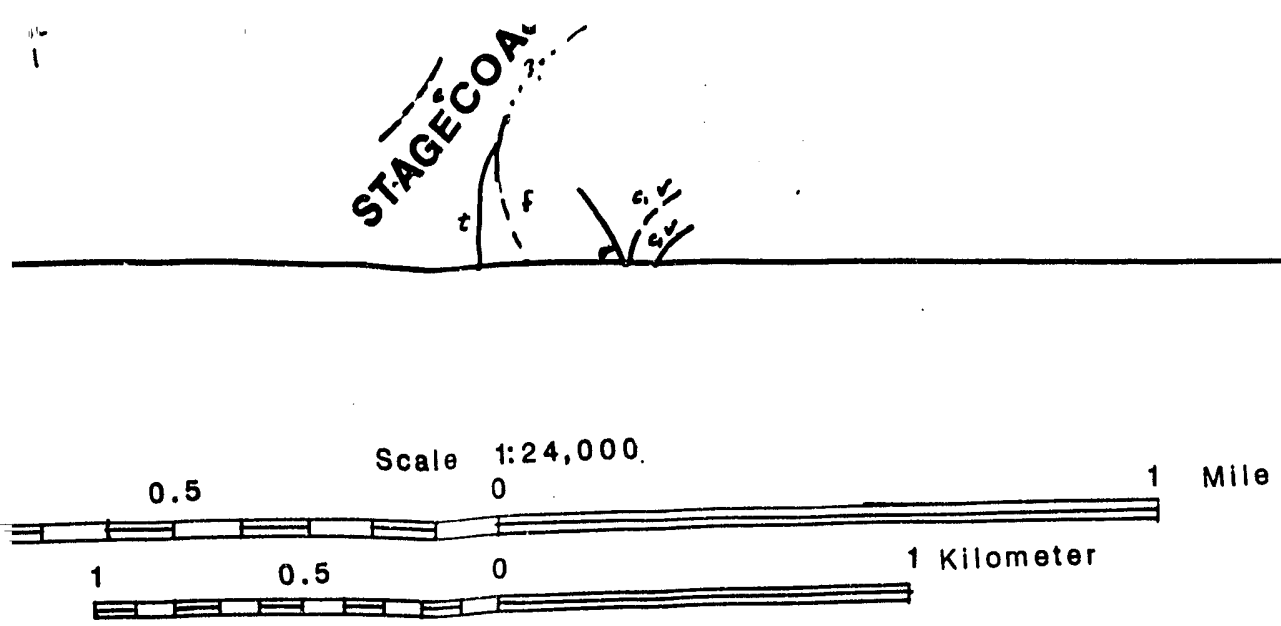

Contour interval 20 foet $-5-\cdots+\cdots \cdot \cdots$

LINEAMENT (approximately k but concealed, 1 Nature of lineament:

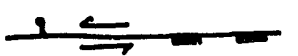

offset of bed

\section{Yucca Mountain, Nye County, Nevada}

Bar

arro

bloc.

v-vegetation

c-tonal contri

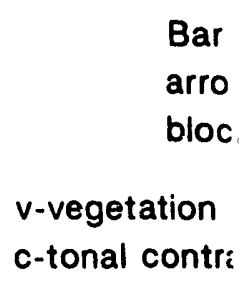

$\frac{1}{4} \quad$ Syncline

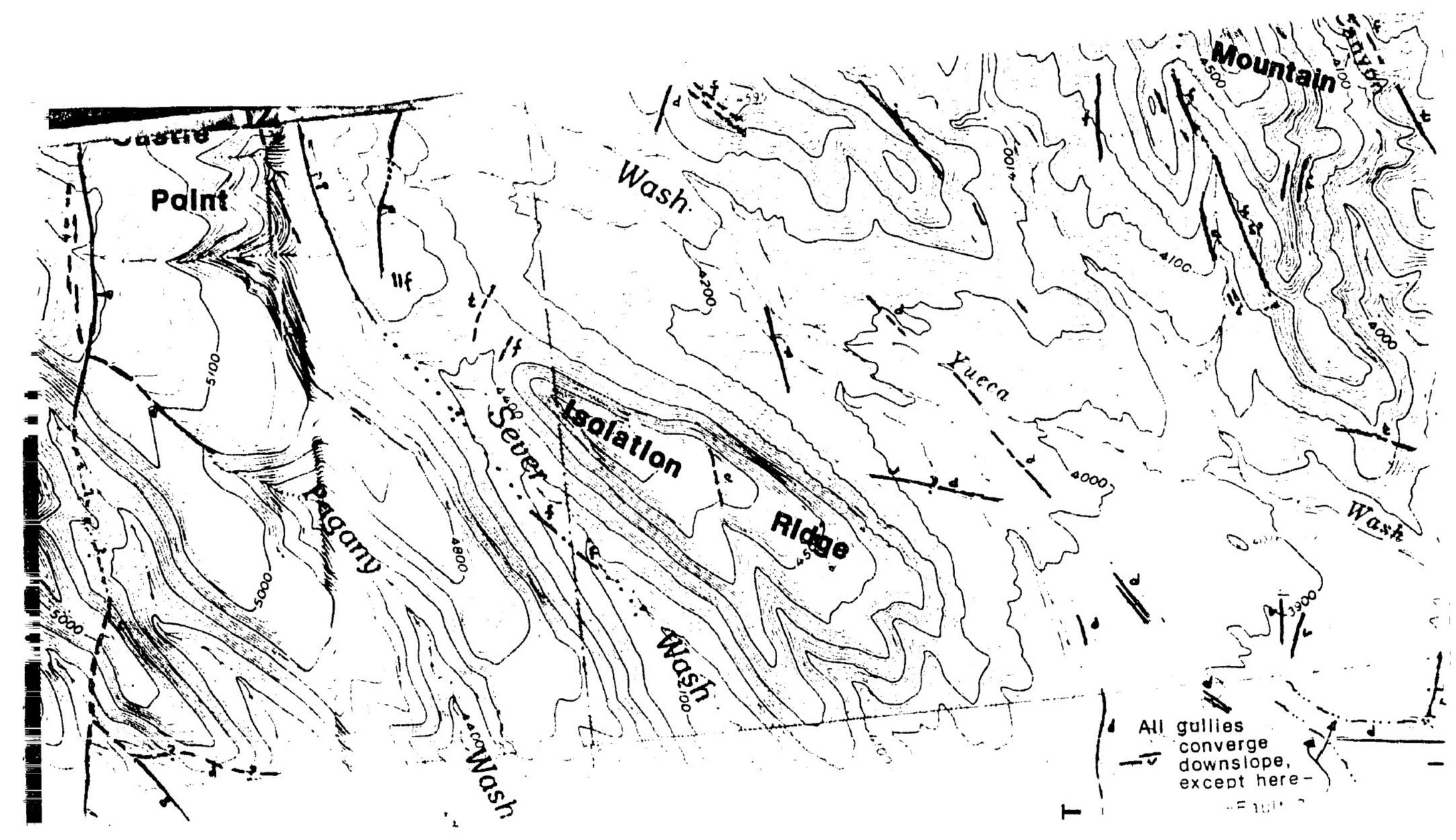




\section{EXPLANATION}

LINEAMENT (approximately located): dashed where poorly displayed, dotted where probable but concealed, queried where questionable

Nature of lineament:

\section{offset of bedrock}

Bar and ball on apparent downthrown side of normal fault; arrows indicate direction of apparent strike-slip displacement; blocks on upthrown side of reverse fault

$v$-vegetation alignment; d-drainage alignment; s-scarp in bedrock/alluvium;

c-tonal contrast; f-fracture; t-topographic or geomorphic feature; i-filled fracture/dike

Syncline

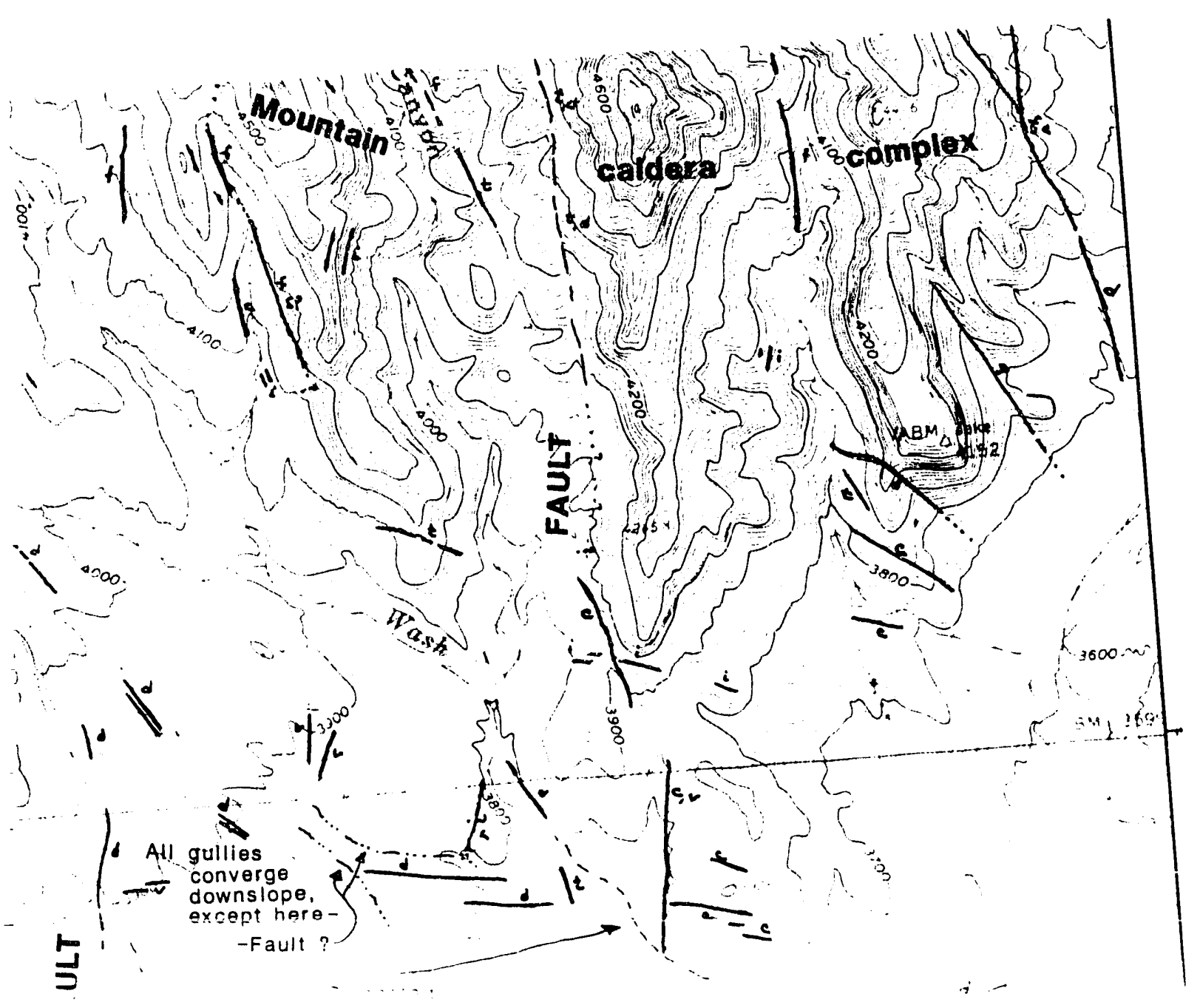



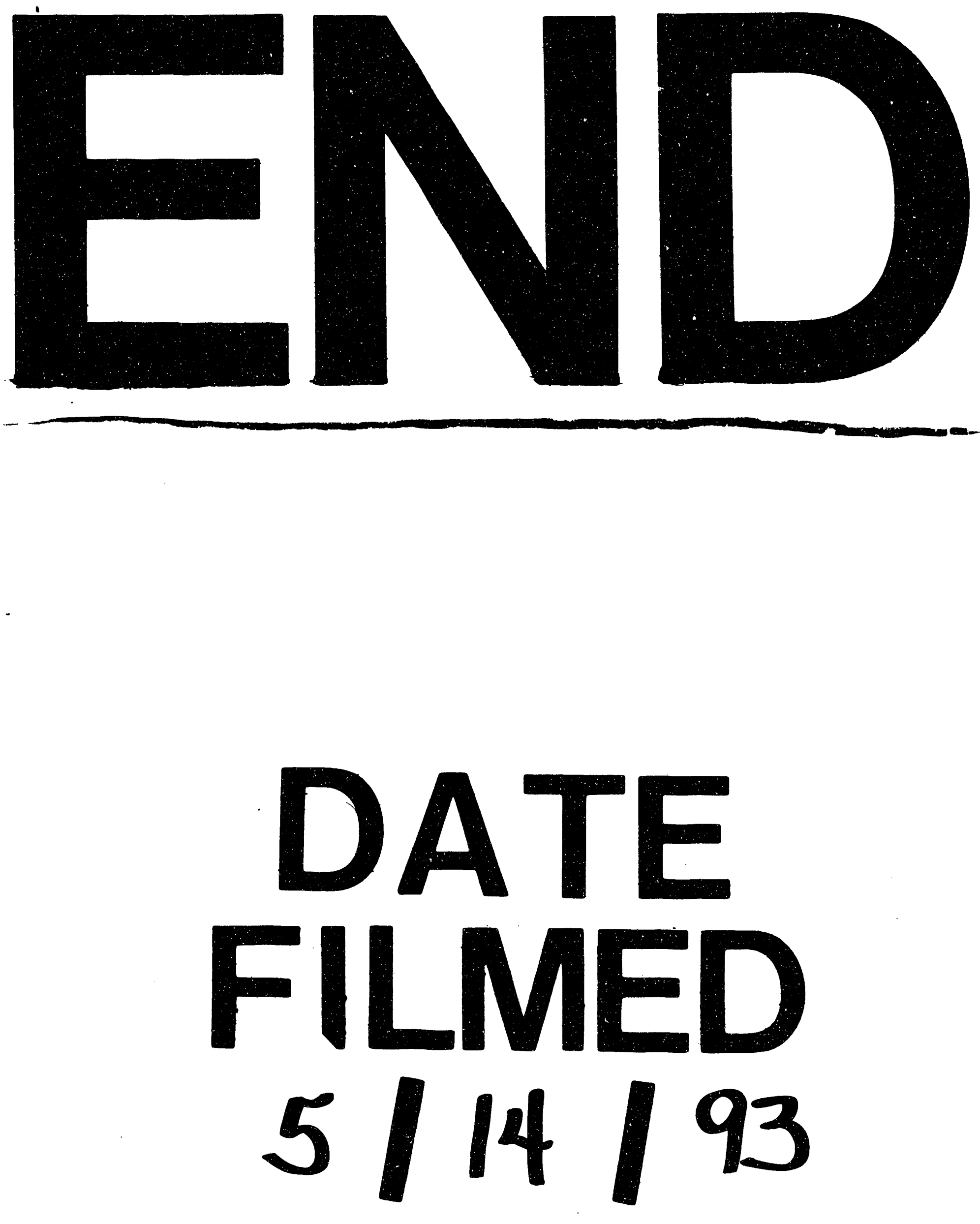